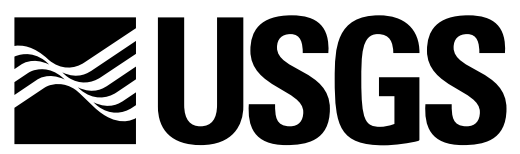

science for a changing world

In cooperation with the United States Army Corps of Engineers New England District

\title{
Analysis of Borehole-Radar Reflection Data from Machiasport, Maine, December 2003
}

Scientific Investigations Report 2005-5087

U.S. Department of the Interior

U.S. Geological Survey 


\section{Analysis of Borehole-Radar Reflection Data from Machiasport, Maine, December 2003}

By Carole D. Johnson and Peter K. Joesten

Prepared in cooperation with the

United States Army Corps of Engineers, New England District

Scientific Investigations Report 2005-5087 


\title{
U.S. Department of the Interior Gale A. Norton, Secretary
}

\author{
U.S. Geological Survey \\ Charles G. Groat, Director
}

U.S. Geological Survey, Reston, Virginia: 2005

For sale by U.S. Geological Survey, Information Services

Box 25286, Denver Federal Center

Denver, CO 80225

\author{
For more information about the USGS and its products: \\ Telephone: 1-888-ASK-USGS \\ World Wide Web: http://www.usgs.gov/ \\ Any use of trade, product, or firm names in this publication is for descriptive purposes only and does not imply \\ endorsement by the U.S. Government. \\ Although this report is in the public domain, permission must be secured from the individual copyright owners to repro- \\ duce any copyrighted materials contained within this report.
}




\section{Contents}

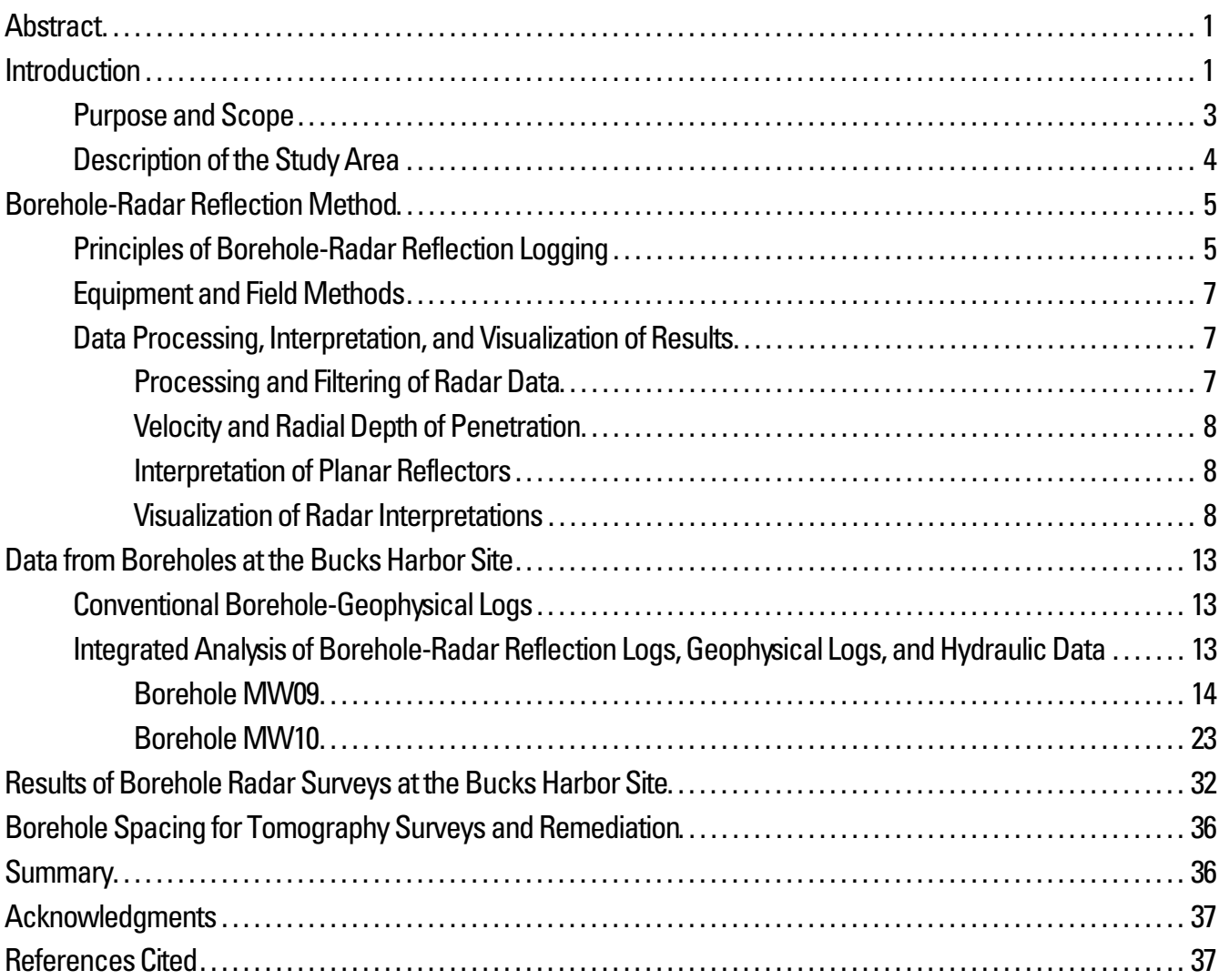

\section{Figures}

1. Map showing location of the boreholes at the former Air Force Radar Tracking Station in

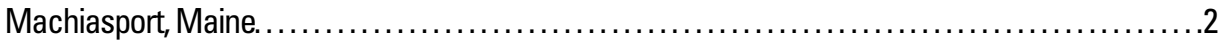

2. Schematic diagram showing methods of borehole-radar data collection. ......................

3. Schematic diagram showing (A) transmitter and receiving antenna arrangementfor single-hole radar-reflection logging, and (B) typical reflection patterns from the direct arrival and planar and

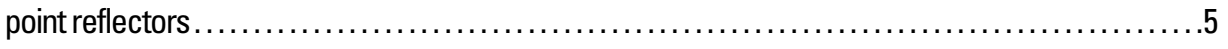

4. Schematic diagram of the borehole, a planar reflector, and the resulting radargram. ..............6

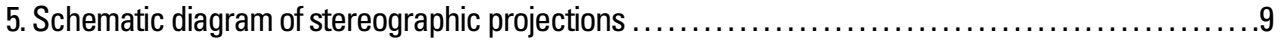

6. Plots showing graphic representation of interpretation of single-hole radar reflectors........... 10

7. Three-dimensional box plot showing all reflectors identified in single-hole reflection logging in MW10 from Machiasport, Maine ............................................... 11

8. Schematic diagram showing radar reflectors projected $(A)$ to the land surface in a block diagram

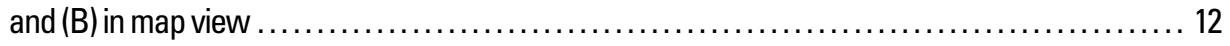

9. Borehole deviation logs for borehole MW09 in Machiasport, Maine ....................... 15

10. Plots showing projection, tadpole, and stereoplot of features interpreted in the acoustic televiewer log for borehole MW09 in Machiasport, Maine ................................... 16

11. Plot showing processed 60-megahert borehole-radar log from borehole MW09 in Machiasport, Maine..... 
12. Plots showing projection, modified tadpole, and stereoplot for radar reflections identified in borehole MW09 in Machiasport, Maine ............................................... 2

13. Borehole deviation logs for borehole MW10 in Machiasport, Maine....................... 24

14. Plots showing projection, tadpole, and stereoplot for optical televiewer (OTV) and acoustic televiewer (ATV) data collected in borehole MW10 in Machiasport, Maine........................ 25

15. Plot showing processed 60-megahert borehole-radar log from borehole MW10 in Machiasport, Maine.

16. Plots showing projection, modified tadpole, and stereoplot for radar reflections identified in borehole MW10 in Machiasport, Maine.

17. Three-dimensional box plot showing directional single-hole borehole-radar reflectors with a continuity factor of 1,2,3, or 4 identified from borehole MW09 in Machiasport, Maine........... 33

18. Three-dimensional box plot showing directional single-hole borehole-radar reflectors with a continuity factor of 1,2, or 3 identified from borehole MW10 in Machiasport, Maine ............. 33

19. Map showing strike of projected reflectors in borehole-radar logs from borehole MW09 in Machiasport, Maine.

20. Map showing strike of projected reflectors in borehole-radar logs from borehole MW10 in Machiasport, Maine.

\section{Tables}

1. Construction of boreholes at the former Air Force Tracking Station area at the Bucks Harbor site, Machiasport, Maine

2. Summary of acoustic televiewer data from borehole MW09 in Machiasport, Maine ....

3. Summary of borehole-radar reflector data from borehole MW09 in Machiasport, Maine......... 22

4. Summary of optical and acoustic televiewer data from borehole MW10 in Machiasport, Maine.

5. Summary of borehole-radar reflector data from borehole MW10 in Machiasport, Maine 


\section{Conversion Factors and Datum}

\begin{tabular}{lll}
\hline \multicolumn{1}{c}{ Multiply } & By & \multicolumn{1}{c}{ To obtain } \\
\hline centimeter $(\mathrm{cm})$ & 0.3937 & inch (in.) \\
meter $(\mathrm{m})$ & 3.281 & foot (ft) \\
meter $(\mathrm{m})$ & 1.094 & yard (yd) \\
kilometer $(\mathrm{km})$ & 0.6214 & mile (mi) \\
\hline
\end{tabular}

Temperature in degrees Celsius $\left({ }^{\circ} \mathrm{C}\right)$ may be converted to degrees Fahrenheit $\left({ }^{\circ} \mathrm{F}\right)$ as follows: ${ }^{\circ} \mathrm{F}=\left(1.8 \mathrm{x}^{\circ} \mathrm{C}\right)+32$.

Vertical coordinate information is referenced to the North American Vertical Datum of 1988 (NAVD 88); horizontal coordinate information is referenced to the North American Datum of 1983 (NAD 83), unless otherwise noted.

All bearings are recorded in azimuthal (0-360) degrees east of magnetic north. By convention, the strikes of planar features are reported azimuthally relative to magnetic north using right-hand rule, which specifies that the dip is always in a direction $90^{\circ}$ to the right of the strike. The direction in which the reflector dips is included for clarity. Hence, a planar feature that strikes south and dips $40^{\circ}$ to the west, would be denoted as $\mathrm{N} 180^{\circ} \mathrm{E}, 40^{\circ} \mathrm{W}$.

\section{Other abbreviations used in this report}

$\begin{array}{ll}\mathrm{L} / \mathrm{min} & \text { liter per minute } \\ \mathrm{MHz} & \text { megahertz } \\ \mathrm{m} / \mu \mathrm{s} & \text { meter per microsecond } \\ \mu \mathrm{s} & \text { microsecond }\end{array}$




\title{
Analysis of Borehole-Radar Reflection Data from Machiasport, Maine, December 2003
}

\author{
By Carole D. Johnson and Peter K. Joesten
}

\section{Abstract}

In December 2003, the U.S. Geological Survey, in cooperation with the U.S. Army Corps of Engineers, collected borehole-radar reflection logs in two boreholes in Machiasport, Maine. These bedrock boreholes were drilled as part of a hydrogeologic investigation of the area surrounding the former Air Force Radar Tracking Station site on Howard Mountain near Bucks Harbor. The boreholes, MW09 and MW10, are located approximately 50 meters $(\mathrm{m})$ from, and at the site of, respectively, the locations of former buildings where trichloroethylene was used as part of defense-site operations. These areas are thought to be potential source areas for contamination that has been detected in downgradient bedrock wells.

This investigation focused on testing borehole-radar methods at this site. Single-hole radar-reflection surveys were used to identify the depth, orientation, and spatial continuity of reflectors that intersect and surround the boreholes. In addition, the methods were used to (1) identify the radial depth of penetration of the radar waves in the electrically resistive bimodal volcanic formation at the site, (2) provide information for locating additional boreholes at the site, and (3) test the potential applications of borehole-radar methods for further aquifer characterization and (or) evaluation of source-area remediation efforts.

Borehole-radar reflection logging uses a pair of downhole transmitting and receiving antennas to record the reflected wave amplitude and transit time of high-frequency electromagnetic waves. For this investigation, 60- and 100-megahertz antennas were used. The electromagnetic waves emitted by the transmitter penetrate into the formation surrounding the borehole and are reflected off of a material with different electromagnetic properties, such as a fracture or change in rock type. Single-hole directional radar surveys indicate the bedrock surrounding these boreholes is highly fractured, because several reflectors were identified in the radar-reflection data. There are several steeply dipping reflectors with orientations similar to the fracture patterns observed with borehole imaging techniques and in outcrops. The radar-reflection data showed that the vitrophyre in borehole MW09 was more highly fractured than the underlying gabbroic unit.

The velocities of radar waves in the bedrock surrounding the boreholes were determined using single-hole vertical radar profiling. Velocities of 114 and 125 meters per microsecond were used to determine the distance to reflectors, the radial depth of penetration, and the dip of reflectors. The bimodal volcanic units appear to be ideal for radar-wave propagation. For the radar surveys collected at this site, radar reflections were detected up to $40 \mathrm{~m}$ into the rock from the borehole. These results indicate that boreholes could conservatively be spaced about 15-20 m apart for hole-to-hole radar methods to be effective for imaging between the boreholes and monitoring remediation. Integrated analysis of drilling and borehole-geophysical logs indicates the vitrophyric formation is more fractured than the more mafic gabbroic units in these boreholes. There does not, however, appear to be a quantifiable difference in the radarwave penetration in these two rock units.

\section{Introduction}

Borehole-radar reflection logs were collected and interpreted for two bedrock boreholes as part of a preliminary test of borehole-radar methods at an environmental restoration site at the former Air Force Radar Tracking Station (AFRTS) in Machiasport, Maine (fig. 1). The site has been classified by the U.S. Department of Defense as a Formerly Used Defense Site (FUDS), and the environmental restoration is managed by the U.S. Army Corps of Engineers (USACE). As part of the ongoing investigations, the U.S. Geological Survey (USGS), in cooperation with the USACE, conducted single-hole radarreflection surveys to identify the location and orientation of reflectors and the projected intersection of the reflectors with the land surface. In addition, each reflector was described in terms of its vertical spatial continuity and relative reflection strength. The radar methods were used to (1) identify the radial depth of penetration of the radar waves in the resistive bimodal volcanic formation at the site, (2) potentially identify new locations for installing boreholes, and (3) test the potential applications of the method for further aquifer characterization and (or) evaluation of remediation efforts.

Borehole-radar methods in single-hole and hole-to-hole modes can be effective for mapping subsurface structures and fluids in fractured-rock and stratified-drift formations surrounding the boreholes (fig. 2). Single-hole reflection surveys have been used to identify and locate individual reflectors that were capable of producing water (Lane and others, 1994; Chapman and Lane, 1996) or were contaminated (Johnson and others, 2001; Green and others, 2004). For these investigations, drilling programs targeted individual reflectors to verify the location and the interpretation of the features. At other sites where the aquifers are intensely fractured, individual reflectors and fractures might not be uniquely identified, but zones of fractures 


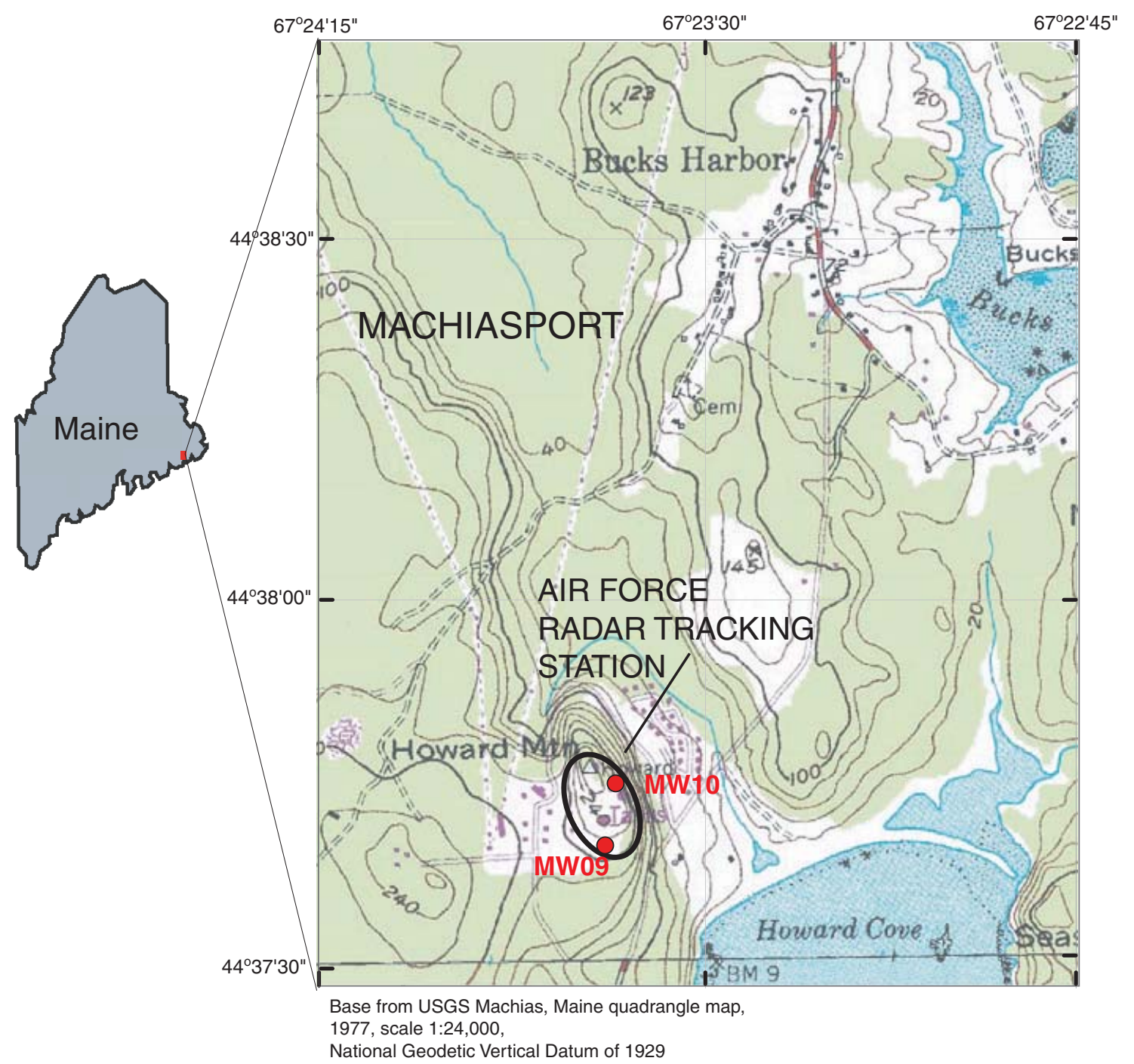

EXPLANATION

Monitoring well and

MW10 identification number

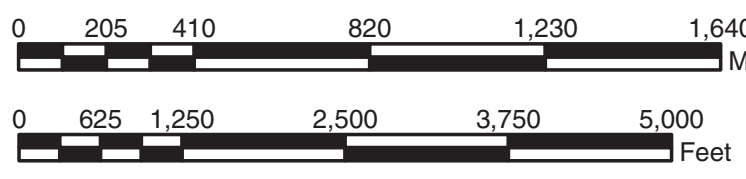

Figure 1. Location of the boreholes at the former Air Force Radar Tracking Station in Machiasport, Maine. This site is part of the U.S. Department of Defense Formerly Used Defense Site (FUDS) environmental restoration program, which is managed by the U.S. Army Corps of Engineers. Map coordinate system is in latitude and longitude. North American horizontal datum of 1927 (NAD27). 
surrounding the borehole have been mapped (Johnson and others, 1999). Crosswell, or hole-to-hole, radar tomography can be used to image the region between two boreholes. Over the past decade, tomographic methods have been used in conjunction with saline tracer tests to map the migration of conductive fluids in the plane between the boreholes (Lane and others, 1996; Day-Lewis and others, 2003; Singha and others, 2003). Tomograms collected before and during tracer tests can be "differenced" to resolve changes in attenuation with time to identify pathways containing the saline tracers. Recent investigations have made use of borehole-radar differencing techniques to monitor the emplacement of remedial agents, such as vegetable oil used for biostimulation (Lane and others, 2004); to verify steam and (or) heat propagation as a part of steam-enhanced remediation in fractured limestone (Gregoire and others, 2004a, 2004b); and to map the emplacement of reactive barriers such as iron-filings walls (Lane and others, 2001).

Prior to mapping active tracers or emplacement of remediation agents, single-hole radar can be used to test the suitability of the site for advanced radar investigations, for assessing the nature of the fracture networks, and for optimizing borehole locations. For the more advanced hole-to-hole radar surveys, the boreholes need to be located such that:

1. the boreholes straddle the zone of interest, which might include a contaminated or transmissive fracture or fracture zone;

2. the interwell separation distance allows radar-wave penetration; and

3. well depth is sufficient to provide good raypath coverage of the plane between the boreholes.

For investigations that are intended to monitor remediation activities, sufficient characterization of the fracturing and local hydraulics is required to verify that the boreholes to be used for the hole-to-hole investigations will straddle the zone of interest. In addition to determining well placement based on the geophysical results, well-field design should include consideration of the hydraulics of the site. Special considerations should address whether any active remediation will include natural gradient flow or forced gradient (pumping) flow. Integrated analyses of borehole-geophysical logs (including flowmeter logging), hydraulic tests, and borehole-radar data can be used to (1) assist the design of a well field that will be adequate to monitor flow and (2) help plan a strategy for remediation.

\section{Previous Investigations}

During the 1990s, the Federal Aviation Administration (FAA) discovered numerous occurrences of ground-water contamination at the former AFRTS (fig. 1) in Machiasport, Maine. During the operation of the base, the U.S. Air Force used solvents, including trichloroethylene [also known as trichloroethene (TCE)], trichloroethane (TCA), and tetrachloroethane (PCE), for automotive maintenance, paint thinning, degreasing, and equipment cleaning (Weston Solutions, 2003). Contaminant distribution data indicated that potential TCE source areas were present in the southern part of Howard Mountain (Weston Solutions, 2003). Because residential wells were contaminated with fuel and TCE, in 1997 the Maine Department of Environmental Protection (MEDEP) ordered the USACE to clean up the site and provide an alternative water supply for local residents (ABB Environmental Services, Inc., 1997).

Several research investigations have addressed the heterogeneous nature of fractured rock and the importance of integrating data from a variety of methods in order to characterize the fractured-rock aquifer (for example, Shapiro and others, 1999). For the former AFRTS, surface-geophysical methods were used as an integral part of project planning to optimize the location of the boreholes to be used for additional subsurface investigation. In February and March 2003, surface-geophysical surveys were conducted to identify possible fracture zones that could potentially serve as contaminant pathways in the crystalline rock (White and others, 2005). Borehole MW09 was installed downgradient of the southern side of Howard Mountain, and borehole MW10 was installed on the east side of the mountain. Both boreholes were installed near potential TCE sources of ground-water contamination. Drilling logs and bedrock core collected from the boreholes were summarized by Weston Solutions (2003). Geophysical logs including caliper, natural gamma, fluid temperature, specific conductance, acoustic and optical imaging, heat-pulse flowmeter under ambient and pumped conditions, and water-quality samples (analyzed for dissolved oxygen, oxidation-reduction potential, and $\mathrm{pH}$ ) were collected in boreholes MW09 and MW10 (Weston Solutions, 2003).

\section{Purpose and Scope}

This report summarizes the purpose, methods of investigation, and results of a borehole-radar investigation at the former AFRTS in Machiasport, Maine. The USGS conducted the investigation in December 2003, in cooperation with the USACE, to evaluate the potential use of borehole radar to (1) map fractures in the bedrock surrounding the boreholes; (2) provide information for locating additional boreholes; and (3) monitor future remediation efforts. As a part of the evaluation, this report summarizes the radar reflectors that were identified in the bedrock surrounding boreholes MW09 and MW10. The report provides a comparison of the results to other borehole-geophysical logs collected from those boreholes, an assessment of the projection of interpreted radar reflectors relative to potential contaminant point sources, and an evaluation of the velocity and radial depth of penetration of radar waves in the bimodal volcanic rocks. 
(A) Reflection

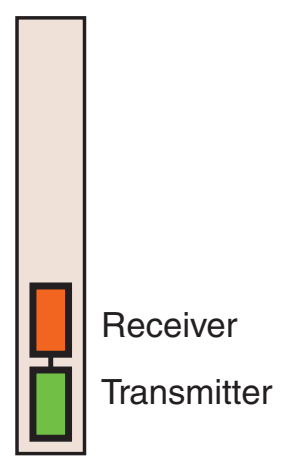

(B) Level-run

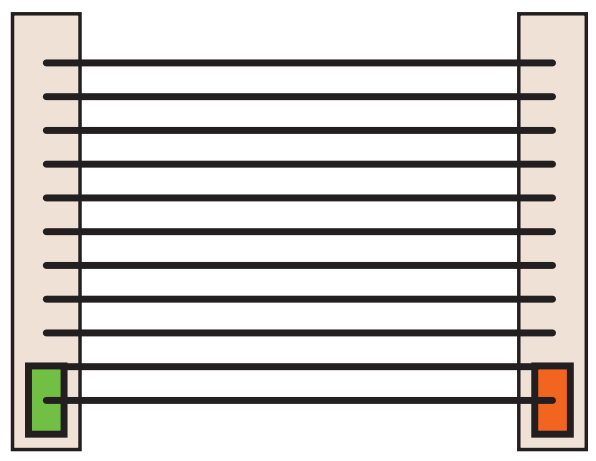

Transmitter
Receiver
(C) Tomography

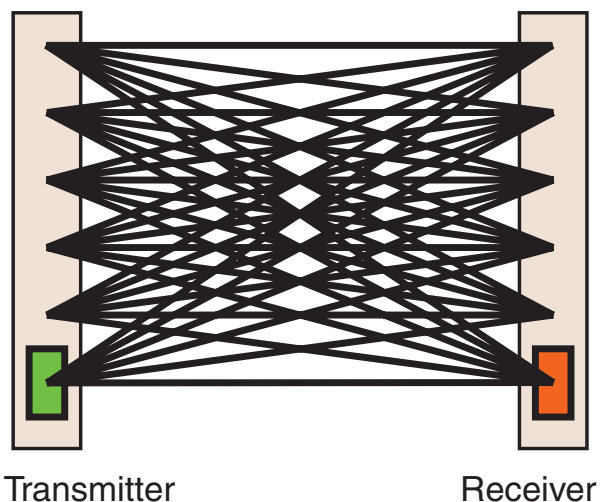

Figure 2. Methods of borehole-radar data collection. Single-hole radar methods include (A) directional and non-directional (or omni-directional) radar surveys in which the receiver and the transmitter are in the same borehole. Hole-to-hole radar surveys include the (B) level-run, in which the transmitter and receiver are kept at the same level, and (C) tomography geometries, in which the receiver logs up and down for each fixed position of the transmitter. In both types of hole-to-hole radar surveys, the region between the boreholes is imaged.

\section{Description of the Study Area}

Borehole-radar investigations were conducted in two boreholes on Howard Mountain at the AFRTS, which is one of three sites that are part of the FUDS environmental restoration program near Machiasport, Maine (fig. 1). Howard Mountain is a small hill that was shaped by tectonics and by glacial and recent erosion. In the area around Howard Mountain, there is a northwest-southeast-oriented drainage pattern that is roughly parallel to the direction of glacial movement and to mapped faults.

Three rock assemblages are mapped in the vicinity of Howard Mountain (Gates and Moench, 1981). The oldest rock unit exposed at the land surface is an early Devonian bimodal volcanic unit (characterized by two distinct mineralogical compositions) of the Eastport Formation. This unit consists of silicic members including a rhyolitic eruptive unit with flow-banded stony vitrophyre, autobreccia, and pyroclastic rock. Dacite and tuff breccias are also present. The early Devonian volcanic unit is the most abundant rock in the area. The unit has been mapped on Howard Mountain southward and eastward to the coast. The bimodal volcanic unit intruded or erupted along a fault bordering the Machias syncline. The second rock unit is a Devonian plutonic igneous unit consisting of hornblende-bearing biotite granodiorite and quartz monzonite (a bimodal suite of gabbro/ granodiorite rocks with quartz diorite to diorite). The granodiorite has been mapped on the northwest side of Howard Mountain. The third rock type in the study area consists of several Silurian-Devonian, northwest-trending diabase and gabbro dikes, sills, and irregular small plutons intruding into the local formations.
Large-scale regional structures include a syncline, normal faults, and block faults. The Machias syncline, a post-early Devonian, northwest-trending fold, consists of the Pembroke Group and Eastport Formation. The Lubec fault zone, a northeast-trending fault, was mapped offshore from the Bucks Harbor site and is characterized by sheared and tightly folded rocks of the Eastport and Quoddy Formations (Gates and Moench, 1981). Subsequent block faulting associated with Silurian volcanism created numerous northwest-trending faults. A large normal fault transects the study area and is coincident with the northwest-southeast trending surface drainage north of Howard Mountain. The fault is mapped from Howard Cove several kilometers to the northwest. Numerous northwest-southeast trending faults dissect the study area with scattered northeast-southwest faulting and folding (Gates, 1981). These faults and fractures appear to have affected the development of the surface drainage and may have strong controls on the flow of ground water within the bedrock aquifer.

Surficial deposit maps indicate that most of the area is covered by a thin veneer of till and brown silty sand and gravel of Pleistocene age (Borns, 1974). Recent mapping and surfacegeophysical studies have identified overburden and fill to depths of 5 meters $(\mathrm{m})$ below land surface (Weston Solutions, 2003; Thompson and others, 2005). The AFRTS site is underlain by highly fractured banded stony rhyolite (Gates and Moench, 1981). Borehole MW09 is located downgradient and southeast of the AFRTS site. Borehole MW10 is on the eastern side of Howard Mountain, adjacent to the AFRTS site and near a steep cliff face that dips east-southeast towards the seacoast. 


\section{Borehole-Radar Reflection Method}

In this study, single-hole borehole-radar reflection methods were used to image the bedrock structures surrounding the boreholes. The radar data were processed and interpreted to identify the depth, orientation, and vertical spatial continuity of reflectors that intersect and surround the boreholes. Two different types of receiving antennas were used for this investigationdirectional and non-directional receiving antennas.

\section{Principles of Borehole-Radar Reflection Logging}

Borehole radar is a geophysical method used to measure contrasts in the electromagnetic properties (primary dielectric permittivity, but also electrical conductivity and magnetic susceptibility) of subsurface materials and the fluids in these materials. In single-hole radar reflection, the transmitting and receiving antennas are in the same borehole (figs. 2 and 3). The transmitting antenna is used to transmit an electromagnetic (EM) pulse containing frequencies in the radar frequency range
(10-1,000 megahertz (MHz)). When an EM pulse impinges upon material with different EM properties, some energy is reflected back and some is transmitted into further materials. Reflected energy is returned to the borehole and recorded by a receiving antenna as a function of time and depth (fig. 3). By profiling along the borehole, a two-dimensional record of EM reflection is created, with depth on the y-axis and two-way radar-wave traveltime on the $\mathrm{x}$-axis (fig. 4A). An analysis of the direct arrival of the radar waves is used to identify low-velocity zones that might be related to fractures or contrasts in rock types (fig. 3B). For directional surveys, a series of two-dimensional records are created every 10 degrees from magnetic north (fig. $4 \mathrm{~B}$ and $4 \mathrm{C})$.

In the schematic shown in figure $4 \mathrm{~A}$, a circular planar fracture is shown dipping and intersecting the borehole, and the upper limb (UL) and lower limb (LL) are shown on the schematic. Adjacent to the schematic is a representative radargram that shows the characteristic chevron-shaped pattern in the reflection profile produced from the intersection of the planar feature with the borehole.
(A)

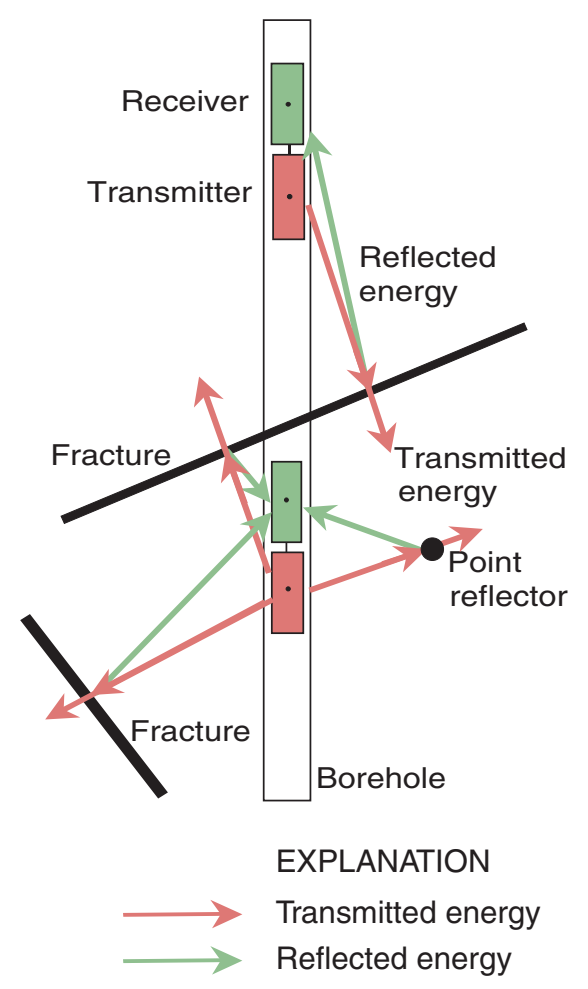

(B)

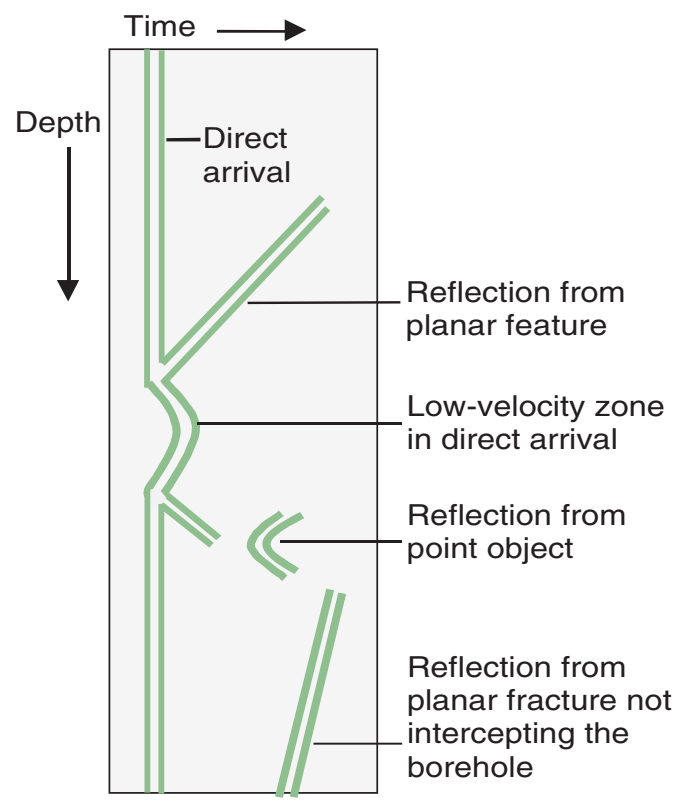

Figure 3. (A) Transmitter and receiving antenna arrangement for single-hole radar-reflection logging, and (B) typical reflection patterns from the direct arrival and planar and point reflectors. 


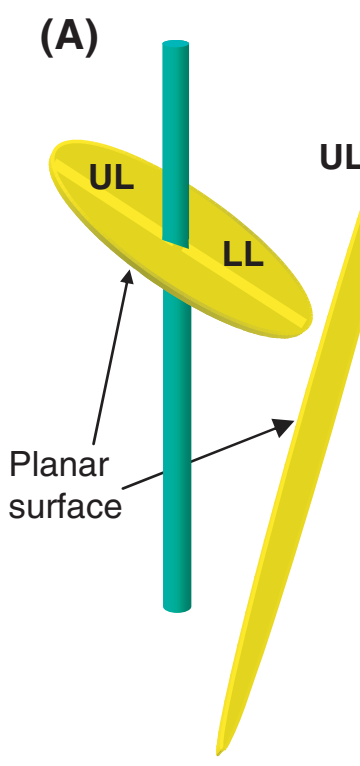

(B)

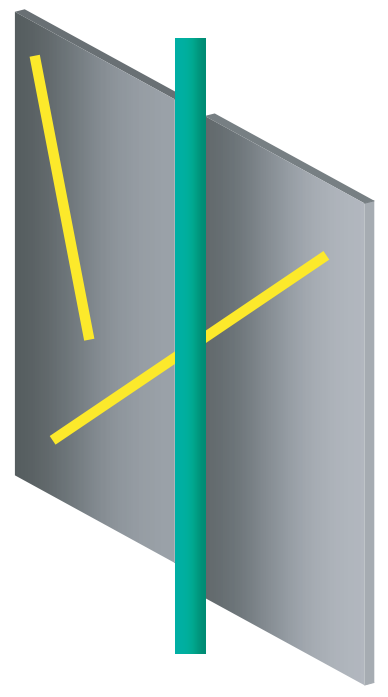

In the directional reflection mode, the reflected signal can be resolved in 36 distinct planes about the borehole. Each plane is analyzed for reflectors. Although a reflection is strongest in one plane, it may be visible in other planes as well.
A radargram, or radar-reflection profile, shows the amplitude of the reflected radar waves as a function of traveltime, which is related to the radial depth of penetration. A planar feature that intersects the borehole, such as a dipping fracture, is characterized by the chevron-shaped pattern (yellow line) in the radargram showing the upper limb (UL) and lower limb (LL) of the fracture. Sometimes only one limb of the reflector can be imaged. Reflectors do not need to intersect the borehole to be interpreted.

\section{RADIAL DISTANCE FROM BOREHOLE}

(C)

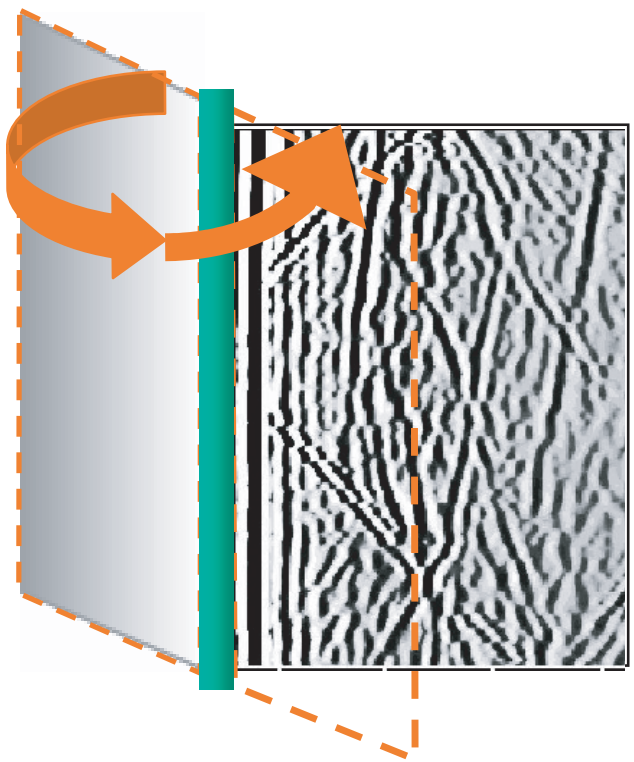

Radar results are depicted in a radargram that shows reflections from both sides of the borehole. Each plane is inspected for planar features, and their depth of intersection with the borehole and dip are determined. The reflector's in-phase and out-of-phase signatures are analyzed. Generally, in the absence of interference, the strike of a reflector can be determined. Occasionally the strike cannot be determined because of noise in the data.

Figure 4. Schematic diagram of the borehole, a planar reflector, and the resulting radargram. 
In borehole-radar reflection, the amplitude and polarity of an EM wave from a reflection is a function of the contrast in the dielectric permittivity of the materials across the interface (Davis and Annan, 1989). The strongest reflections are produced from the interface of materials with contrasting EM properties such as rock and water or rock and air. Therefore, reflections are likely from air- or fluid-filled fractures, faults, bedding, changes in rock type or water quality, and possibly from flow-banded fabric within the volcanic rocks. The total radial penetration of EM waves into the formation depends on the electrical resistance of the rock and water surrounding the borehole, and on antenna frequency and separation. In electrically conductive rocks, such as in shale units or sulfide layers, the EM waves are rapidly attenuated, severely reducing penetration to a few meters or eliminating penetration. Radial penetration is best in resistive rocks such as granite or rhyolite. Borehole-radar reflection data are interpreted to determine the location and orientation of reflections from fracture zones, voids, and lithologic changes, and to estimate the radial extent of planar reflectors. The borehole-radar tool provides the ability to detect reflections and anomalies beyond the borehole wall and provide information on the fracture network that would not be detected with other borehole tools.

\section{Equipment and Field Methods}

Based on methods described in Lane and others (1994), single-hole directional-radar reflection surveys were conducted in the two bedrock boreholes to determine the orientation and location of discrete fractures or fracture zones surrounding the borehole. For this investigation, a Mala GeoScience RAMAC radar system was used. The radar tool was configured with a broadband electric-dipole transmitting antenna and a dual-loop directional-receiving antenna with a three-component directional magnetometer. Both transmitter and receiver have center frequencies of $60 \mathrm{MHz}$ in air. The center points of the antennas were separated by a common-offset distance of $6.41 \mathrm{~m}$. Radar measurements were made every 20 centimeters $(\mathrm{cm})$ along the open portion of each logged borehole. A total of 64 complete scans were stacked (averaged) at each measurement location to enhance the signal quality.

The magnetometer in the directional borehole-radar receiver requires a calibration specific for the geographic location. The calibration was conducted according to the instructions from the manufacturer at a location free of known magnetic, EM, and cultural interference. The calibration was not conducted at the AFRTS site on Howard Mountain because of electromagnetic and cultural interference. The calibration data were collected in Meddybemps, Maine, which is about 40 kilometers $(\mathrm{km})$ away. The data were collected relative to magnetic north, which is $18.1^{\circ}$ west of true north in Machiasport, Maine. For this investigation, the orientations were not converted to true north but were reported relative to magnetic north so they would be comparable to previously reported borehole data (Weston Solutions, 2003).
Based on methods described in Lane and others (1994), single-hole omni-directional radar surveys were also conducted in the two bedrock boreholes. The omni-directional surveys were collected using a Mala GeoScience RAMAC radar system. A dipole transmitter and receiver with a center frequency of $100 \mathrm{MHz}$ in air were used. A common-offset distance of $2.79 \mathrm{~m}$ separated the center points of the antennas. A total of 128 complete scans were stacked at each measurement location to enhance the signal quality. These "dipole radar" (non-directional or omni-directional) surveys can determine the dip of a reflector, but cannot be used to determine the strike of a reflector. They are used because the higher frequency antennas can provide a more detailed radar image than the lower-frequency directional antennas. From the dipole-radar image, the dip of the reflectors and the depth of intersection (or projection of the depth of intersection) with the borehole can be determined.

The complete length of each open borehole was logged with the radar tool. Because the total tool length is about $10.4 \mathrm{~m}$, the deepest measuring point in the borehole is about $6 \mathrm{~m}$ above the bottom of the borehole; however, reflectors in the record can project deeper than the borehole, as well as above the borehole.

\section{Data Processing, Interpretation, and Visualization of Results}

The processed borehole-radar data are shown with directwave and reflection amplitudes plotted as a function of depth in meters (for example, fig. 4A). The horizontal axis represents the two-way traveltime, in microseconds, as well as the radial distance from the borehole, in meters. Interpretation included the determination of the strike, dip, and projected borehole-intersection depth of planar reflectors as well as determination of the distance to point-like reflectors used to estimate depth of penetration. Methods of interpretation are described by Falk (1992) and Olsson and others (1992).

\section{Processing and Filtering of Radar Data}

Data processing of non-directional and directional radar reflection surveys included removal of direct-current offsets, application of linear and exponential gains, and band-pass filtering to remove random and coherent noise. For both directional and non-directional data, high- and low-pass filtering was applied (30 to $70 \mathrm{MHz}$ for the directional data and 70 to $120 \mathrm{MHz}$ for the non-directional data) to remove random highand low-frequency noise. For the dipole (non-directional) data, a moving-average filter was applied to minimize the direct arrival and near-vertical fractures so as to better image the nonvertical reflectors near the borehole. 


\section{Analysis of Borehole-Radar Reflection Data from Machiasport, Maine, December 2003}

\section{Velocity and Radial Depth of Penetration}

An estimate of radar-wave velocity is needed for data processing, interpretation of the dip of radar reflectors, and estimates of the depth of penetration. Because the radar velocities are formation dependent, the vertical radar profiling (VRP) analyses were conducted in each of the boreholes. In MW10, the analysis was conducted for both the saturated and unsaturated sections of the borehole. In VRP analysis, the distance between the transmitter and receiver is increased by keeping the transmitter at a fixed location while incrementally increasing the offset distance; the traveltime of the direct wave between the transmitter and the receiver then is measured for each depth increment. From the known geometry and the measured traveltime, the radar-wave velocities of the rock surrounding the borehole are calculated.

\section{Interpretation of Planar Reflectors}

In the RAMAC processing software, after the data have been filtered and processed, planar features are manually fit to the radar reflectors observed in the radargrams. For the omnidirectional data, the radargram shows the reflections from all around the borehole in a single plane. The depth of penetration and resolution of data collected with the omni-directional antenna generally is better than data collected with the directional antenna. Hence, the omni-directional data provide valuable information that cannot always be observed in the directional data. The directional antenna resolves the radar response from discrete planes surrounding the boreholes (fig. 4B and $4 \mathrm{C})$. Each reflection in the radargram is analyzed separately. For the directional reflection data, the orientation of the reflection relative to magnetic north is determined by how the reflected radar wave impinges on the loop antennas, which is determined by analyzing the polarity of the upper limb and the lower limb of the reflection. A simulated "dipole" dataset is made from the sum of the four loop antenna measurements. This dipole value is compared to the phase of the interpreted reflector to determine the strike of the reflector. In the software, the reflection is observed in the plane of its maximum reflection response and then is observed in planes at $+90^{\circ},+180^{\circ}$, and $+270^{\circ}$, such that the reflection is in-phase and then out-ofphase. In the best situation, both limbs are clearly viewed and an interpretation of structure can be made. In cases where the phase of the reflector cannot be determined, the strike of the reflector can only be resolved in some direction $\pm 180^{\circ}$.

The reflectors were assigned a score depending on the continuity and strength of the reflector. A score of 1 indicates a very good, continuous reflector and a score of 5 indicates a poor reflector of sporadic continuity across the radargram. The location and orientation of reflectors are presented in tables and figures. For some reflectors, there are interferences from other features that preclude the determination of strike. In addition, if a reflecting feature is non-planar, it can also prevent the determination of strike, dip, or point of intersection. However, the reflector's dip and the depth of intersection with the borehole can be determined, even if the strike cannot be determined. The directional confidence factor indicates the certainty associated with the azimuthal direction of the reflector ( 1 indicates very certain and 5 indicates almost no certainty).

The interpretations of radar reflectors from the both the directional and non-directional radargrams are combined in a single table for each borehole. By convention, the strikes of planar features are reported azimuthally relative to magnetic north $\left(0-360^{\circ}\right.$ east of magnetic north) using the right-hand rule, which specifies that the dip is always in a direction $90^{\circ}$ to the right of the strike. Hence, a planar feature that strikes south and dips $40^{\circ}$ to the west, would be denoted as $\mathrm{N} 180^{\circ} \mathrm{E}, 40^{\circ} \mathrm{W}$. The dip azimuth, or direction in which the reflector dips relative to magnetic north, is also shown in the tables.

\section{Visualization of Radar Interpretations}

In addition to lists in the tables, the interpretations of radar reflectors are shown graphically in a variety of representations. Typically, the orientations (strike and dip) of radar reflectors are plotted in stereoplots, where the pole to the plane of a reflector is projected from a lower hemisphere to an equatorial plotting surface (fig. 5). A stereoplot reduces each planar feature to a point that represents the intersection of a pole that is perpendicular to the plane. Hence, the points on the plotting circle, which represents the equatorial plane of the hemisphere, are called "poles to planes." In this type of a plot, a nearly horizontal fracture would have a pole that projects near the center of the stereoplot. The pole of a steeply dipping fracture would project near the outside edge of the stereoplot and would be located on the side of the circle opposite from the direction of dip. The stereoplots provide a graphical method for assessing the clustering or variability of the poles to planes. One drawback of the stereoplot is that it includes only features where both strike and dip could be determined. Moreover, it does not indicate the projected depth of intersection of the reflectors with the borehole. Stereoplots were produced for each borehole.

In this report, interpretations of planar features are shown in adjacent projection, tadpole, and stereoplots (fig. 6). Collectively, these plots can be used to help assess the spatial distribution and variability of oriented datasets, such as fractures and radar reflectors. The projection plot uses a color-coding scheme (fig. 6A) to show the sine-wave trace of a planar feature on a log column with a horizontal axis that represents compass directions and a vertical axis that represents depth (fig. 6B). Projection plots generally show the distribution of fractures or reflectors with respect to depth. The tadpole plot (fig. 6C) is effective in showing the orientation of a fracture or a reflector as a function of depth. The tadpole plot shows the depth of the feature along the vertical axis; the magnitude of dip from 0 to $90^{\circ}$ along the horizontal axis; and the direction of dip (dip azimuth), which is represented by the direction of the tadpole's tail. The tail of the tadpole points in a direction of dip azimuth relative to an imaginary compass with north at the top of the plot. The tadpole plot can be used to help identify distinct changes in orientation over the depth of the borehole. 


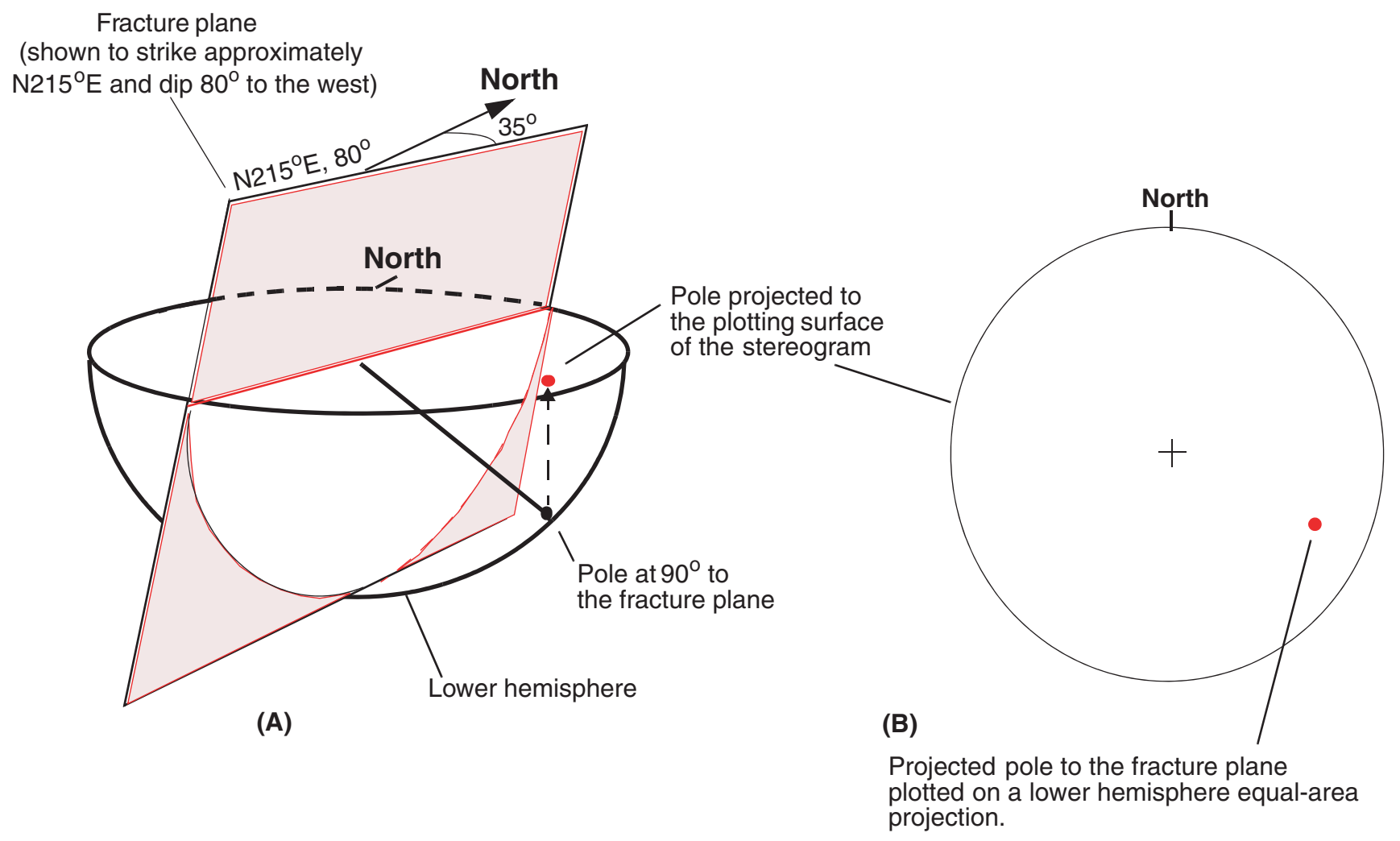

Figure 5. Schematic diagram of stereographic projections. The stereographic projection reduces the orientation of a fracture plane or planar reflector to a point on the stereogram by plotting the pole to the plane on a lower hemisphere and projecting it up to the plotting surface of the stereogram. In this investigation, all fractures were oriented relative to magnetic north.

For radar-reflection data, the projected depth of intersection is shown on the y-axis of the tadpole plot. For reflectors whose strike and dip were determined, the orientation can be plotted the same as in a standard tadpole plot as described above (fig. 6C). Different colors and symbols were used to represent the interpreted radar reflectors (fig. 6A). Tadpoles were shown in different colors to more readily indicate which features with a strike and dip were correlated to borehole image logs (red tadpole) and which were not (light blue tadpole). For this investigation, the tadpole plot was modified to accommodate reflectors that cannot be included in a stereoplot because their strikes could not be determined. Reflectors whose strike could not be determined were plotted in green with a modified tadpole, where the tadpole has no tail. The tadpole (a circle) reflects only the depth of penetration and the angle of dip. Reflectors whose strike only could be resolved to a direction $\pm 180^{\circ}$ were plotted in pink with a modified tadpole with two tails that point in opposite directions. The two tails indicate the two possible directions of the dip. Modified tadpole plots were produced for both boreholes, and all reflectors identified in each of the boreholes were included.
To aid in the visualization of the radar reflectors, a cubic three-dimensional (3D) representation was generated using FRACVIEW software (Paul Hsieh, USGS, written commun., 1997). In this representation, the borehole-radar reflectors are shown as disk-shaped planar features with a uniform diameter of $15 \mathrm{~m}$. The dimensions of the cube are 200 by 150 by $150 \mathrm{~m}$. The upper surface of the cube, which is shaded, represents the land surface. The northern side of the cube and magnetic north are indicated with a line on the northern side of the cube. Figures were produced for each of the boreholes; however, only reflectors whose strike and dip could be determined were included in the representation. FRACVIEW allows the user to rotate the cube and see the reflectors from multiple perspectives. The cube can be rotated or tipped as seen in the movie (fig. 7). The reflectors were color coded such that green disks in the cube plot represent reflectors that project to above the top of the open hole. Yellow disks in the 3D cube plot represent reflectors that project to below the casing in the boreholes. Red and blue disks represent reflectors that could only be resolved to $\pm 180^{\circ}$. 
(A) Symbols for interpreted radar reflectors

(B) Projection

(C) Modified Tadpole

(D) Stereoplot

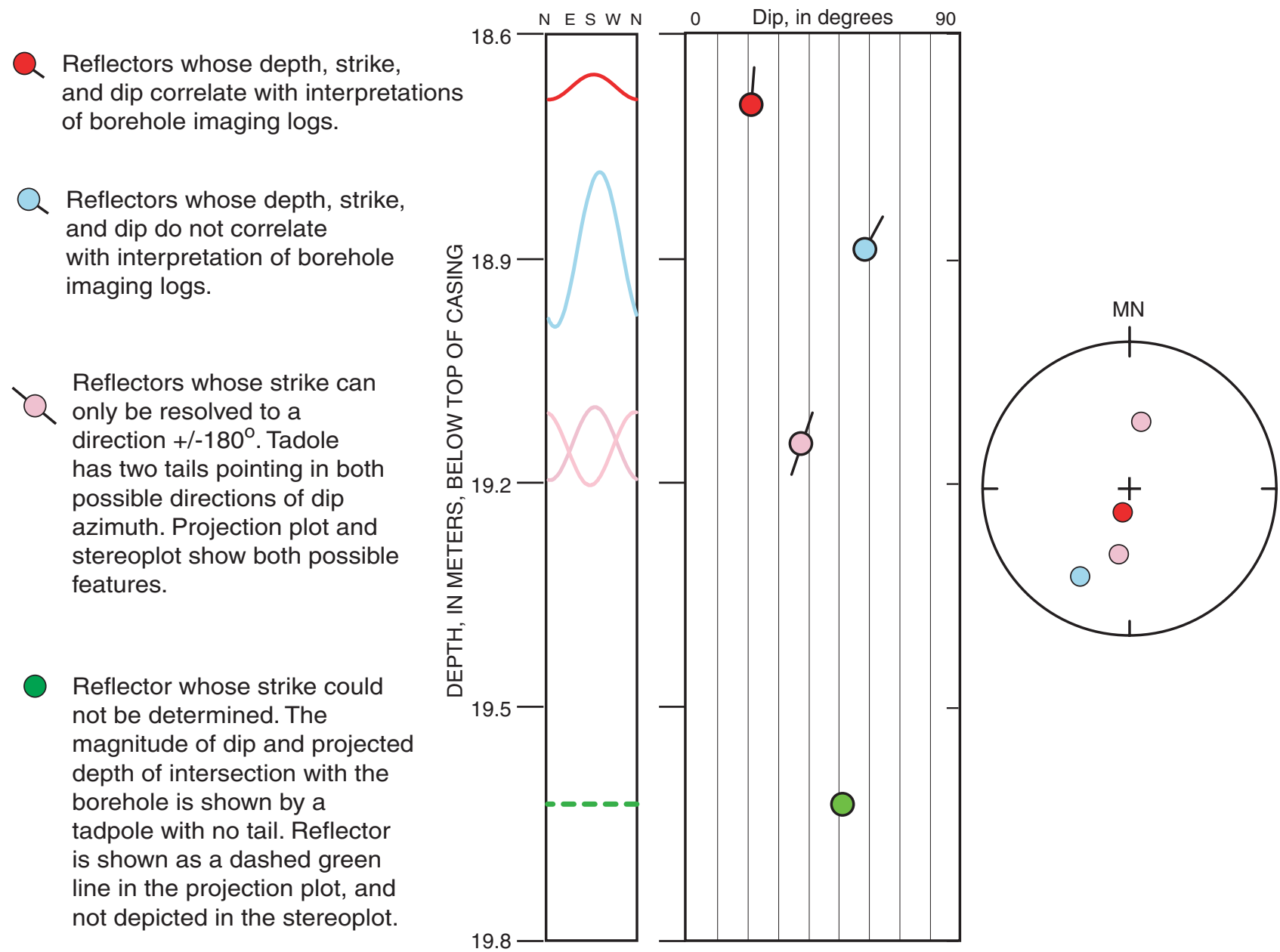

Figure 6. Graphic representation of interpretation of single-hole radar reflectors.

(A) Symbols (and colors) used in this investigation to represent the planar features identified in borehole-radar logs.

(B) Projection plot shows where the radar reflectors are projected to intersect the borehole. Depth of projected intersection is plotted along the vertical axis. The bottom of the sine wave indicates the dip azimuth relative to magnetic north (MN), which is shown along the horizontal axis. Dashed green lines indicate reflectors where the strike could not be determined, and hence, only the depth of the reflector is represented.

(C) Modified tadpole plot—-depth is plotted along the vertical axis and the magnitude of dip is plotted on the $x$ axis. The tail of the tadpole points in the direction of dip relative to magnetic north, which is at the top of the page.

(D) Stereographic projection plots. The poles to the planar features are shown in a lower-hemisphere equal-area stereonet for features where strike and dip could be determined. 


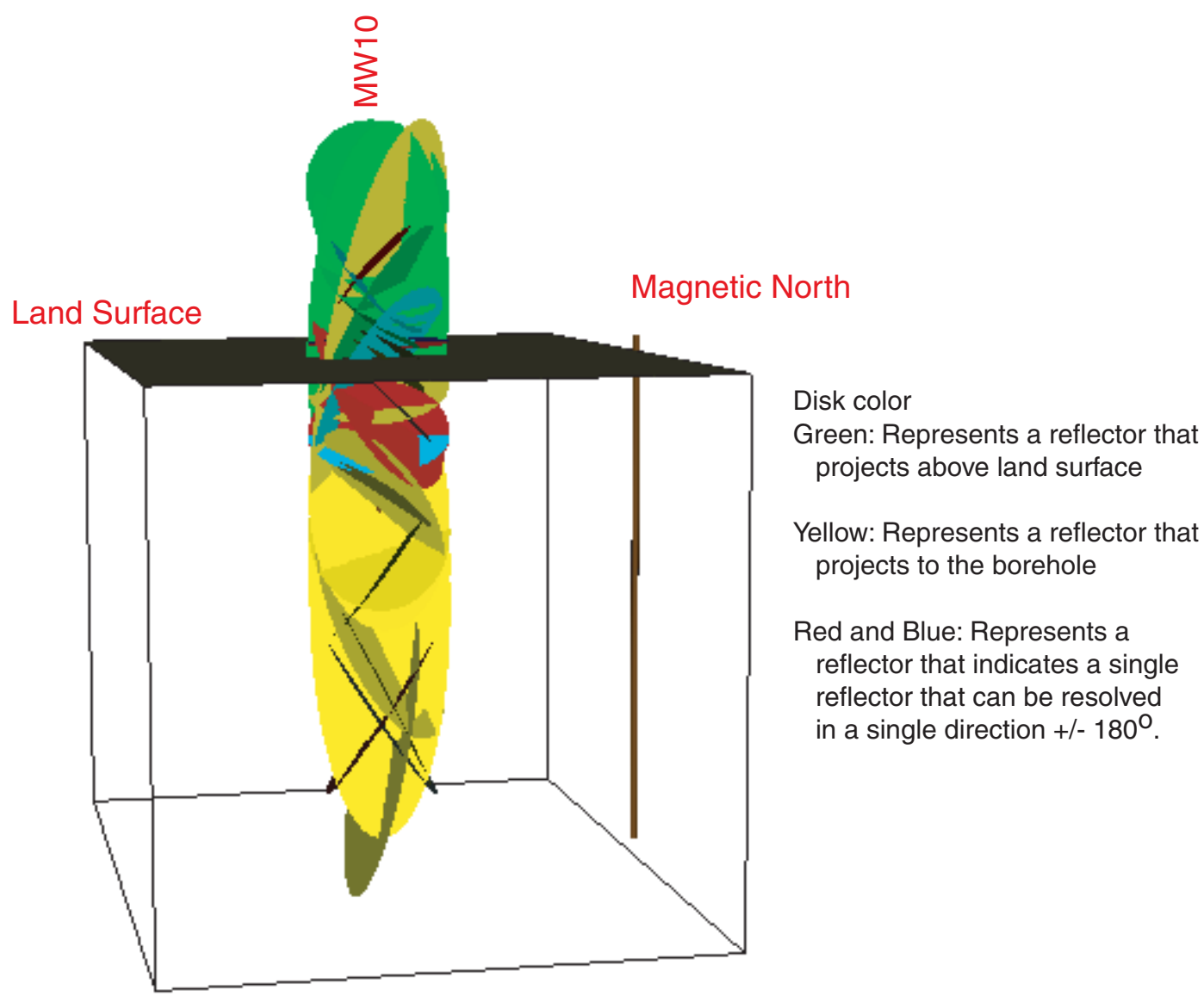

Figure 7. All reflectors identified in single-hole reflection logging in MW10 from Machiasport, Maine. Results are presented in a 3-dimensional box plot. Magnetic north is identified as a brown line on the right side of this figure. (To launch the movie, click on this link.)

In addition to the 3D representation, the reflectors whose orientation could be determined in the radar data were projected along their orientation to determine the general intersection of the plane with the land surface (fig. 8A). This extension of the planes assumes the reflectors are infinitely extensive, the borehole is straight, the bedrock extends to the land surface, and the land is continuous to the point of intersection with the plane. The intersection of the projected plane with the land surface was arbitrarily shown in map view as a $20-\mathrm{m}$-long line (fig. 8B). A solid line was used for reflectors where the strike and dip could be resolved, and two dashed lines were used to represent the strike of the line for reflectors that could only be resolved to $\pm 180^{\circ}$. This analysis was conducted to help visualize the reflectors that might project towards, or originate near, the location of former buildings that were identified as possible point sources for TCE contamination. Because of the limiting assumptions used for this analysis, the projections should only be used to help visualize the plan-view pattern of radar reflections rather than used as an exact map of the fractures around the boreholes. Plan-view plots of the reflector's intersection with the land surface were produced for each borehole. 


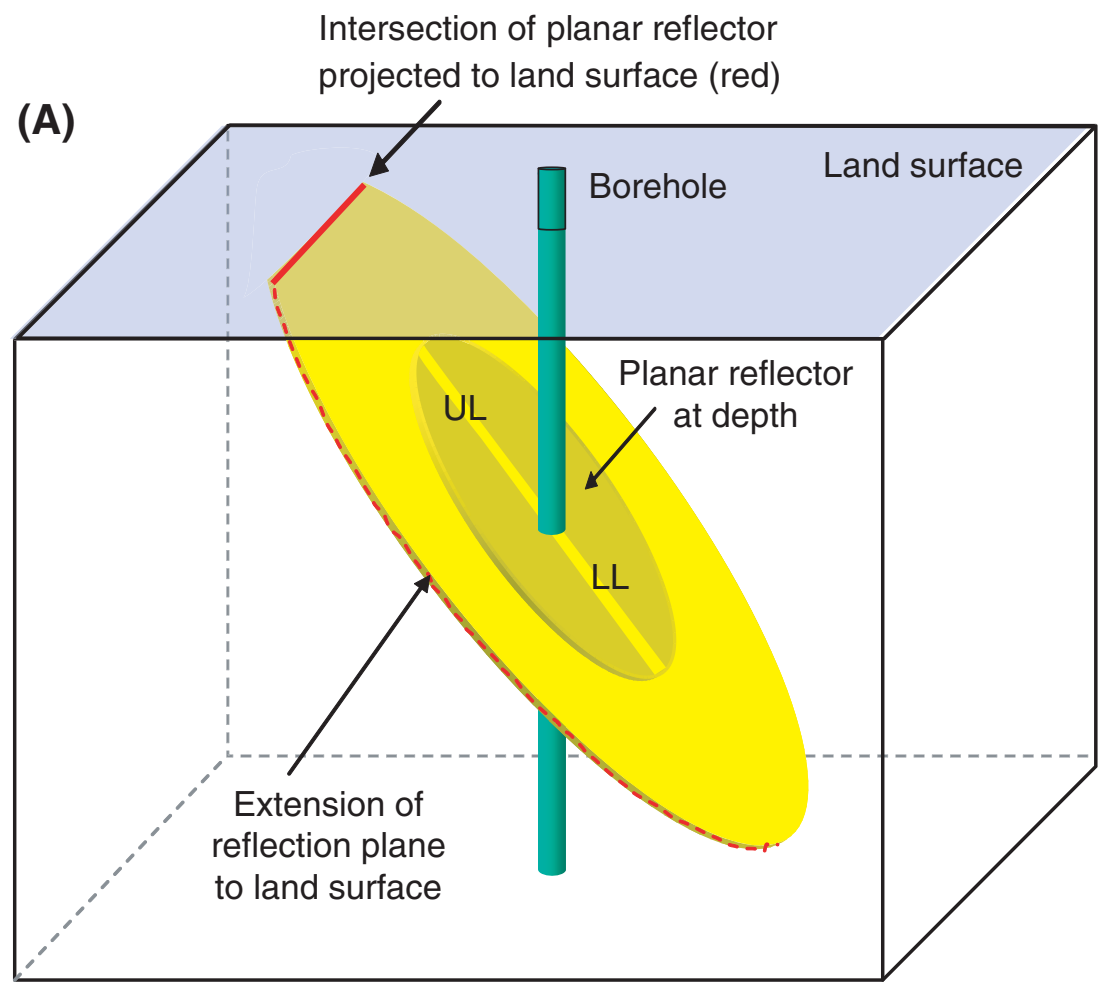

(B)

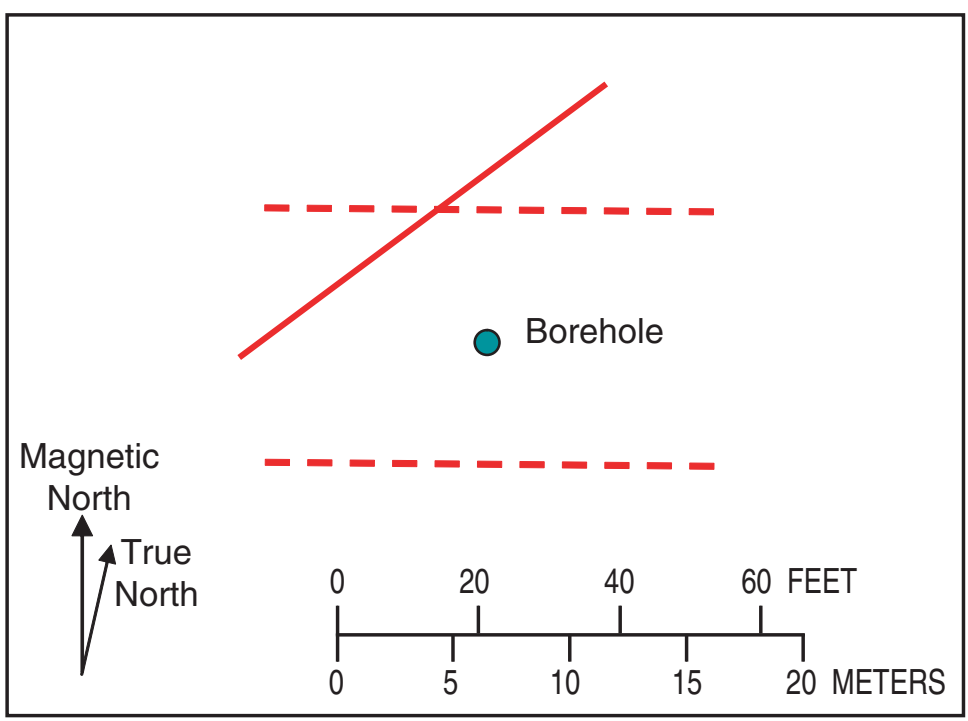

Figure 8. Schematic diagram showing radar reflectors projected $(A)$ to the land surface in a block diagram and $(B)$ in map view. For this interpretation, the intersection of the plane with the land surface was set at 20 meters. A solid line was used for reflectors where the strike and dip could be resolved, and two dashed lines were used to represent the strike of the line for reflectors that could only be resolved to $\pm 180^{\circ}$. 


\section{Data from Boreholes at the Bucks Harbor Site}

For this investigation, borehole-geophysical logging was conducted in two bedrock boreholes, MW09 and MW10, from December 9-11, 2003. The boreholes are approximately $10 \mathrm{~cm}$ in diameter and completed to depths of 35.7 and $60.2 \mathrm{~m}$ (about 120 and $200 \mathrm{feet}$ ), respectively, below land surface. Information on borehole construction and location is provided in table 1.

\section{Conventional Borehole-Geophysical Logs}

A complete suite of conventional borehole-geophysical logs was collected in both of the bedrock boreholes as a part of an earlier investigation to evaluate the lithology, fracturing, and hydraulics in boreholes at the AFRTS site (Weston Solutions, 2003). Natural gamma, EM induction, normal resistivity, spontaneous potential, and single-point resistance logs were used to determine properties of the geologic formation. Mechanical caliper, acoustic televiewer (ATV), and optical televiewer (OTV) logs were used to identify the location and orientation of fractures that intersect the borehole. Fluid properties of the aquifer were determined using the fluid-logging tool, which measures the specific conductance, temperature, $\mathrm{pH}$, oxidation-reduction potential, and percent oxygen of the water in the borehole column. The heat-pulse flowmeter was used to measure vertical flow as low as 0.04 liters per minute $(\mathrm{L} / \mathrm{min})$ in the borehole and to determine the location of inflow and outflow locations under pumping and ambient conditions. In conjunction with the measured fluid properties, the heat-pulse flowmeter data were used to identify hydraulically active fractures that intersect the borehole. Where appropriate, the results from the conventional logs are discussed in order to provide an integrated interpretation of the radar logs.

Borehole deviation, which was collected concurrently with ATV images, is shown in a radial plot for each borehole. The center of the plot represents the borehole location at the top of casing. In the radial plot, the borehole location is plotted as a function of depth with respect to true north. In addition, a crosssectional plot of the borehole deviation is provided for a selected azimuthal direction, typically the direction in which the borehole deviates. Although the magnitude of the deviation for the boreholes generally was small, the data were used to correct the orientations of the features observed in the boreholes to account for the borehole inclination. Deviation data are critical for any hole-to-hole or surface-to-borehole radar investigations, because small changes in distance can have a large impact on computed velocity (Day-Lewis and others, 2003).

\section{Integrated Analysis of Borehole-Radar Reflection Logs, Geophysical Logs, and Hydraulic Data}

Detailed interpretations of directional and non-directional radar data are provided for boreholes MW09 and MW10. In addition, an integrated interpretation of the radar data along with the borehole-imaging data is reported in the following section.

Table 1. Construction of boreholes at the former Air Force Tracking Station area at the Bucks Harbor site, Machiasport, Maine.

[Distances are in meters]

\begin{tabular}{lccccccc}
\hline $\begin{array}{c}\text { Borehole } \\
\text { name }\end{array}$ & Date drilled & $\begin{array}{c}\text { Height of } \\
\text { casing above } \\
\text { land surface }\end{array}$ & $\begin{array}{c}\text { Casing } \\
\text { material }\end{array}$ & $\begin{array}{c}\text { Depth of } \\
\text { casing below } \\
\text { land surface }\end{array}$ & $\begin{array}{c}\text { Elevation of } \\
\text { land surface }\end{array}$ & $\begin{array}{c}\text { Total depth } \\
\text { below land } \\
\text { surface }\end{array}$ & $\begin{array}{c}\text { Depth of } \\
\text { overburden } \\
\text { from } \\
\text { drilling log }\end{array}$ \\
\hline MW09 & $6 / 22 / 2003$ & 0.88 & steel & 2.74 & 59.61 & 35.69 & 0.76 \\
MW10 & $6 / 20 / 2003$ & 0.81 & steel & 5.79 & 74.45 & 60.15 & 3.96 \\
\hline
\end{tabular}

${ }^{1}$ Information from drilling logs (Weston Solutions, 2003). 


\section{Analysis of Borehole-Radar Reflection Data from Machiasport, Maine, December 2003}

\section{Borehole MW09}

Location and construction. Borehole MW09 is located on Howard Mountain off of the paved access road, behind the parking lot, and about $50 \mathrm{~m}$ southwest from the former location of Building 501, where TCE was reportedly used (fig. 1)

(Weston Solutions, 2003). Borehole MW09 is a 10-cm diameter borehole drilled using air-hammer rotary methods. Steel casing was set to $2.74 \mathrm{~m}$ to prevent flow between the unconsolidated sediments and the bedrock. The top of bedrock was reported as $0.76 \mathrm{~m}$ below land surface (Weston Solutions, 2003). Below the steel casing, MW09 is open to a depth of $35.69 \mathrm{~m}$ below land surface. The borehole location was selected to evaluate subsurface structures and the depths of radar penetration in the rhyolite vitrophyre and mafic gabbro rock units, and to identify and delineate fractures capable of transporting ground-water contamination in the area of Building 501.

MW09 deviates about $1.7 \mathrm{~m}$ towards the east (fig. 9). The open-hole ambient water level was $2.38 \mathrm{~m}$ below land surface on December 9, 2003. Borehole-radar data were collected relative to top of casing and were corrected in post processing to land surface, which is $0.88 \mathrm{~m}$ below the top of steel casing.

Lithologic and fracture characterization. Borehole MW09 intersects rhyolitic flow-banded vitrophyre and autobreccia and a more mafic unit at depth. The gamma, electromagnetic induction, and ATV logs indicate a change in bedrock at a depth of about $23 \mathrm{~m}$ below land surface. The logs show a reduction in natural gamma emissions and a small increase in conductivity below a depth of $23 \mathrm{~m}$. These emissions (about 50 counts per second) were similar to the emissions from the bedrock at the bottom of MW14, a borehole about $2.5 \mathrm{~km}$ northnortheast of the field site that was cored and interpreted as gabbro (Weston Solutions, 2003). The ATV also showed a change in the amplitude of the reflected wave in borehole MW09 at this depth, and it appeared to stay uniform to the bottom of the borehole. Collectively, these changes are all consistent with a change in rock type as noted in the drilling records.

The fractures identified in ATV logs in MW09 show a wide variation in strike and dip at shallow to steep angles. The majority of features in the ATV log, however, are steeply dipping (greater than $50^{\circ}$ from horizontal). The depths and orientations of all fractures identified in the ATV logs of MW09 are listed in table 2 (Weston Solutions, 2003). Features that were observed on both the amplitude plot and the transit time plot of the ATV logs were described as "open features." All other features were designated as "less-open features." Stereoplots for MW09 show some clustering of the poles to planes of fractures as interpreted in ATV logs (fig. 10). The more prominent open features in the ATV $\log$ (shown in red) tend to strike east and dip to the south, and some strike west and dip to the north. The less prominent, minor features show more variability in orientation. The minor features (shown in light blue) strike west and dip over a range of angles to the south and strike east and dip over a range of angles to the north. Almost all other features in the borehole are steeply dipping and strike over a range from south to west and dip west to north. The upper rhyolite vitrophyre shows higher density of fracturing than the lower more mafic unit.

Ambient downflow and upflow was measured in the borehole, with the fracture at $23.1 \mathrm{~m}$ receiving the flow within the borehole. Under ambient conditions, water entered the borehole at $8.3 \mathrm{~m}$ and flowed downward, and concurrently entered the borehole at the fracture at $33.5 \mathrm{~m}$ and flowed upward exiting at $23.1 \mathrm{~m}$ below land surface. Under pumping conditions, all inflow occurred between the bottom of casing and $4.6 \mathrm{~m}$ below land surface. The specific conductance, percent oxygen, and $\mathrm{pH}$ $\operatorname{logs}$ indicated that the fracture at $23 \mathrm{~m}$ is hydraulically active, which supports the interpretation of the other logs.

Velocity and radial penetration distance in MW09. For borehole MW09, VRP analyses indicated there are two very different rock types over the length of the borehole, thus two different velocities were used for the interpretation. For reflectors identified in the radar image above $22 \mathrm{~m}$ below land surface, a velocity of 125 meters per microseconds $(\mathrm{m} / \mu \mathrm{s})$ was used. For reflectors identified below $22 \mathrm{~m}$, a velocity of $114 \mathrm{~m} / \mu \mathrm{s}$ was used. In MW09, the radial penetration distance of the directional tool was $22 \mathrm{~m}$, whereas the radial penetration distance of the non-directional tool was $18 \mathrm{~m}$ from the borehole. 


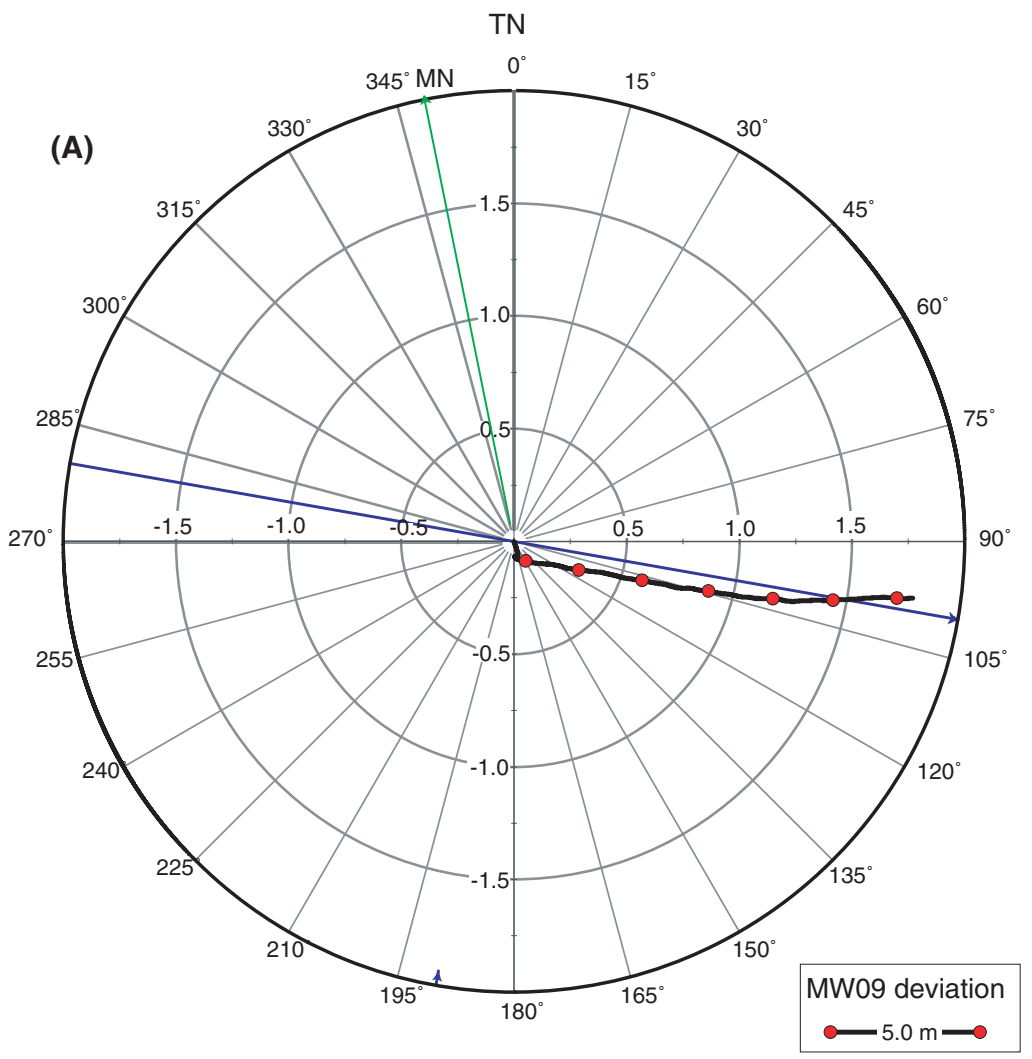

(B) OFFSET, IN METERS ALONG BEARING N100E

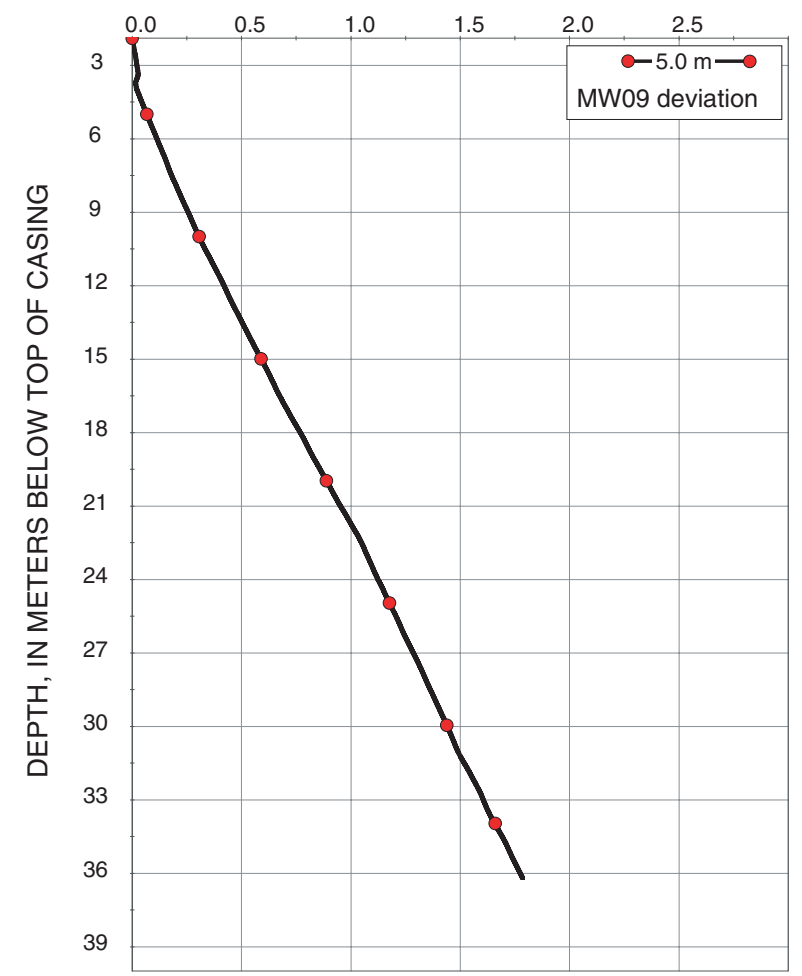

Figure 9. Borehole deviation logs for borehole MW09 in Machiasport, Maine. (A) Radial deviation plot in 5-meter depth increments. (B) Cross-sectional view of borehole deviation in meters along a bearing of $N 100^{\circ} \mathrm{E}$, which is shown as a blue line in the radial plot. [TN, true north; MN magnetic north] 


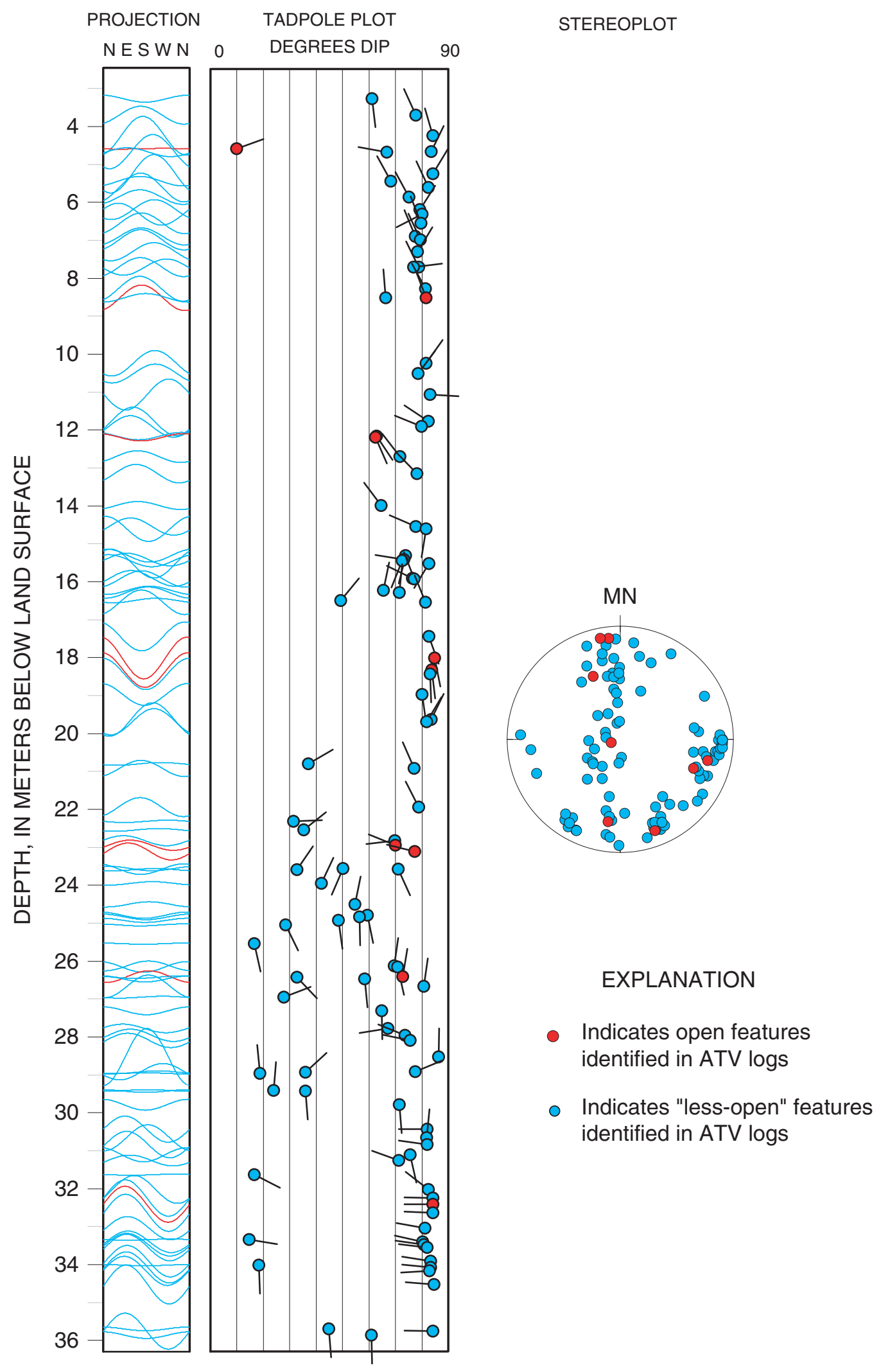

Figure 10. Projection, tadpole, and stereoplot of features interpreted in the acoustic televiewer (ATV) log for borehole MW09 in Machiasport, Maine. Interpretations of ATV logs are from Weston Solutions (2003). All orientations are relative to magnetic north (MN). 
Table 2. Summary of acoustic televiewer data from borehole MW09 in Machiasport, Maine.

[Data modified and reinterpreted from Weston Solutions, 2003]

\begin{tabular}{|c|c|c|c|c|}
\hline $\begin{array}{l}\text { Depth, in meters } \\
\text { below land surface }\end{array}$ & Dip azimuth & Strike $^{1}$ & $\operatorname{Dip}^{1}$ & Description \\
\hline 3.3 & 173 & 83 & 59 & less-open feature \\
\hline 3.7 & 336 & 246 & 78 & less-open feature \\
\hline 4.2 & 344 & 254 & 86 & less-open feature \\
\hline 4.6 & 58 & 328 & 8 & open feature \\
\hline 4.7 & 26 & 296 & 83 & less-open feature \\
\hline 4.7 & 280 & 190 & 69 & less-open feature \\
\hline 5.3 & 31 & 301 & 84 & less-open feature \\
\hline 5.4 & 331 & 241 & 70 & less-open feature \\
\hline 5.6 & 335 & 245 & 84 & less-open feature \\
\hline 5.9 & 332 & 242 & 77 & less-open feature \\
\hline 6.2 & 32 & 302 & 78 & less-open feature \\
\hline 6.3 & 243 & 153 & 83 & less-open feature \\
\hline 6.5 & 339 & 249 & 81 & less-open feature \\
\hline 6.9 & 337 & 247 & 79 & less-open feature \\
\hline 7.0 & 335 & 245 & 81 & less-open feature \\
\hline 7.3 & 31 & 301 & 77 & less-open feature \\
\hline 7.7 & 334 & 244 & 81 & less-open feature \\
\hline 7.7 & 83 & 353 & 74 & less-open feature \\
\hline 8.3 & 332 & 242 & 83 & less-open feature \\
\hline 8.5 & 339 & 249 & 83 & open feature \\
\hline 8.5 & 355 & 265 & 68 & less-open feature \\
\hline 10.2 & 34 & 304 & 80 & less-open feature \\
\hline 10.5 & 36 & 306 & 77 & less-open feature \\
\hline 11.1 & 93 & 3 & 80 & less-open feature \\
\hline 11.8 & 303 & 213 & 86 & less-open feature \\
\hline 11.9 & 293 & 203 & 83 & less-open feature \\
\hline 12.2 & 147 & 57 & 61 & less-open feature \\
\hline 12.2 & 158 & 68 & 61 & open feature \\
\hline 12.7 & 322 & 232 & 74 & less-open feature \\
\hline 13.2 & 316 & 226 & 81 & less-open feature \\
\hline 14.0 & 322 & 232 & 67 & less-open feature \\
\hline 14.5 & 293 & 203 & 81 & less-open feature \\
\hline 14.6 & 189 & 99 & 82 & less-open feature \\
\hline 15.3 & 194 & 104 & 74 & less-open feature \\
\hline 15.4 & 279 & 189 & 77 & less-open feature \\
\hline 15.5 & 203 & 113 & 73 & less-open feature \\
\hline 15.5 & 211 & 121 & 84 & less-open feature \\
\hline 15.9 & 296 & 206 & 80 & less-open feature \\
\hline 15.9 & 338 & 248 & 79 & less-open feature \\
\hline 16.2 & 10 & 280 & 66 & less-open feature \\
\hline 16.3 & 5 & 275 & 72 & less-open feature \\
\hline 16.5 & 37 & 307 & 48 & less-open feature \\
\hline 16.5 & 338 & 248 & 83 & less-open feature \\
\hline 17.4 & 160 & 70 & 81 & less-open feature \\
\hline 18.0 & 169 & 79 & 84 & open feature \\
\hline 18.3 & 174 & 84 & 84 & open feature \\
\hline 18.4 & 178 & 88 & 83 & less-open feature \\
\hline 19.0 & 172 & 82 & 79 & less-open feature \\
\hline 19.6 & 25 & 295 & 82 & less-open feature \\
\hline 19.7 & 31 & 301 & 80 & less-open feature \\
\hline
\end{tabular}


Table 2. Summary of acoustic televiewer data from borehole MW09 in Machiasport, Maine. - Continued

[Data modified and reinterpreted from Weston Solutions, 2003]

\begin{tabular}{|c|c|c|c|c|}
\hline $\begin{array}{l}\text { Depth, in meters } \\
\text { below land surface }\end{array}$ & Dip azimuth & Strike $^{1}$ & $\operatorname{Dip}^{1}$ & Description \\
\hline 20.8 & 57 & 327 & 34 & less-open feature \\
\hline 20.9 & 336 & 246 & 79 & less-open feature \\
\hline 21.9 & 333 & 243 & 81 & less-open feature \\
\hline 22.3 & 86 & 356 & 28 & less-open feature \\
\hline 22.5 & 48 & 318 & 33 & less-open feature \\
\hline 22.8 & 264 & 174 & 72 & less-open feature \\
\hline 22.9 & 292 & 202 & 73 & open feature \\
\hline 23.1 & 284 & 194 & 80 & open feature \\
\hline 23.6 & 206 & 116 & 51 & less-open feature \\
\hline 23.6 & 156 & 66 & 70 & less-open feature \\
\hline 23.6 & 30 & 300 & 32 & less-open feature \\
\hline 23.9 & 21 & 291 & 41 & less-open feature \\
\hline 24.5 & 9 & 279 & 54 & less-open feature \\
\hline 24.8 & 170 & 80 & 59 & less-open feature \\
\hline 24.8 & 181 & 91 & 56 & less-open feature \\
\hline 24.9 & 174 & 84 & 48 & less-open feature \\
\hline 25.0 & 159 & 69 & 27 & less-open feature \\
\hline 25.5 & 177 & 87 & 16 & less-open feature \\
\hline 26.1 & 7 & 277 & 70 & less-open feature \\
\hline 26.2 & 168 & 78 & 70 & less-open feature \\
\hline 26.4 & 8 & 278 & 73 & open feature \\
\hline 26.4 & 140 & 50 & 30 & less-open feature \\
\hline 26.5 & 176 & 86 & 58 & less-open feature \\
\hline 26.7 & 8 & 278 & 80 & less-open feature \\
\hline 27.0 & 68 & 338 & 25 & less-open feature \\
\hline 27.3 & 181 & 91 & 65 & less-open feature \\
\hline 27.8 & 261 & 171 & 70 & less-open feature \\
\hline 28.0 & 292 & 202 & 76 & less-open feature \\
\hline 28.1 & 282 & 192 & 79 & less-open feature \\
\hline 28.5 & 1 & 271 & 86 & less-open feature \\
\hline 28.9 & 67 & 337 & 75 & less-open feature \\
\hline 28.9 & 45 & 315 & 34 & less-open feature \\
\hline 29.0 & 346 & 256 & 19 & less-open feature \\
\hline 29.4 & 357 & 267 & 24 & less-open feature \\
\hline 29.4 & 179 & 89 & 36 & less-open feature \\
\hline 29.8 & 176 & 86 & 71 & less-open feature \\
\hline 30.4 & 270 & 180 & 85 & less-open feature \\
\hline 30.7 & 6 & 276 & 82 & less-open feature \\
\hline 30.8 & 277 & 187 & 85 & less-open feature \\
\hline 31.1 & 169 & 79 & 75 & less-open feature \\
\hline 31.2 & 290 & 200 & 75 & less-open feature \\
\hline 31.6 & 124 & 34 & 13 & less-open feature \\
\hline 32.0 & 308 & 218 & 85 & less-open feature \\
\hline 32.3 & 272 & 182 & 88 & less-open feature \\
\hline 32.4 & 270 & 180 & 88 & open feature \\
\hline 32.6 & 273 & 183 & 88 & less-open feature \\
\hline 33.0 & 281 & 191 & 84 & less-open feature \\
\hline 33.3 & 103 & 13 & 12 & less-open feature \\
\hline 33.4 & 283 & 193 & 83 & less-open feature \\
\hline 33.5 & 278 & 188 & 84 & less-open feature \\
\hline
\end{tabular}


Table 2. Summary of acoustic televiewer data from borehole MW09 in Machiasport, Maine. - Continued

[Data modified and reinterpreted from Weston Solutions, 2003

\begin{tabular}{ccccc}
\hline $\begin{array}{c}\text { Depth, in meters } \\
\text { below land surface }\end{array}$ & Dip azimuth & Strike $^{1}$ & Dip $^{1}$ & Description \\
\hline 33.6 & 277 & 187 & 85 & less-open feature \\
33.9 & 279 & 189 & 87 & less-open feature \\
34.0 & 188 & 98 & 19 & less-open feature \\
34.1 & 275 & 185 & 87 & less-open feature \\
34.2 & 267 & 177 & 86 & less-open feature \\
34.5 & 275 & 185 & 88 & less-open feature \\
35.7 & 178 & 88 & 45 & less-open feature \\
35.8 & 271 & 181 & 87 & less-open feature \\
35.9 & 180 & 90 & 61 & less-open feature \\
\hline
\end{tabular}

${ }^{1}$ Strike and dip are presented in the right-hand rule where the strike is in degrees east of magnetic north and the dip direction is to the right of the strike.

Borehole-radar reflectors in MW09. The highest amplitude radar reflectors in the radargram (fig. 11) project to intersect the borehole near or above the top of the borehole. These reflectors are high-resolution and strong features that project to the line of the borehole at $-39.6,-9.5,-0.7$, and $-0.3 \mathrm{~m}$ below land surface (table 3 ). It is unlikely that these features extend as far down in depth as indicated on the radargram; rather, it is thought this is an artifact of the image. Because of strong interference, the strikes of these features were difficult to determine. Moreover, from the data it was unclear which side of the borehole these features are on and where they might project, which might be important for understanding the site. The features that project to intersect the borehole at $4.5 \mathrm{~m}$ strike about $\mathrm{N} 240^{\circ} \mathrm{E}$ and dip steeply about $70^{\circ}$ to the northwest. In general, the locations of the poles to the reflector planes (fig. 12) are consistent with the clusters identified in the stereoplots for the ATV data (fig. 10). Because there were relatively few radar reflectors whose strike and dip could be determined or because of the variability of the reflector orientations, the poles to reflector planes form only "weak" clusters, at best (fig. 12). The radar reflectors in MW09 strike southwest and dip at a variety of angles to the northwest and strike east-northeast and dip south-southeast.

A total of 45 reflectors were interpreted from the boreholeradar reflection data collected in MW09 (fig. 11). Five of the reflectors correlate to features interpreted in the ATV log for MW09, and are shown in red in the projection and tadpole plots for MW09 (fig. 12). Some of these features were very subtle in the radargram, but location and orientation compare well to the ATV data. Seven reflectors (shown in light blue) are projected to intersect the borehole in the casing or above the land surface; however not all of these were shown in the tadpole plot, which was terminated at $50 \mathrm{~m}$ above the land surface. Nine other reflectors that do not correlate with the ATV are projected to intersect below the bottom of the borehole, with the deepest reflector projected to a depth of about $90 \mathrm{~m}$. These reflectors are also shown in light blue in figure 12. Five reflectors had strike values that could be resolved only to $\pm 180^{\circ}$. They were shown as pink tadpoles with two tails, and with both possible poles to the planes in the stereoplot (fig. 12).

Although the numbers of poles in the stereoplot were sparse, more radar interpretations were displayed in the projection and tadpole plots by including features whose strike and dip direction could not be resolved. The projection, tadpole, and stereoplots for MW09 indicate there were many reflectors whose strike could not be determined. The vertical distribution of tadpoles shows there are numerous reflectors that project to the open part of the borehole. There are more radar reflectors that project to intersect the upper part of the borehole above $23 \mathrm{~m}$ where the change in lithology was observed. The distribution of tadpoles along the horizontal axis indicates that many of these features are steeply dipping, which is consistent with the features observed in the ATV logs for this borehole.

In radargrams, large water-filled fractures are often identified by an increase in the attenuation of radar signals and a decrease in the velocity of radar-wave propagation (Chapman and Lane, 1996). Two fractures that were observed in MW09 in the ATV $\log$ at 4.57 and $33.53 \mathrm{~m}$ below land surface were identified as transmissive with the heat-pulse flowmeter. These features were also identified in the borehole-radar data at about the same depths; however, no change in the attenuation was associated with these features. A feature in the ATV $\log$ at $23 \mathrm{~m}$, which has been interpreted as the transmissive zone, was receiving water under ambient conditions, and appeared to have a small decrease in the velocity of radar waves. Because the radar velocity remained constant in the lower part of the borehole, it is likely that the decrease in radar velocity is associated with the change in the rock type that occurs at $23 \mathrm{~m}$. The decrease in velocity is minor, about $11 \mathrm{~m} / \mu \mathrm{s}$; however, there was no real change in attenuation associated with the change in rock type at about $23 \mathrm{~m}$ below land surface. 
TWO-WAY TRAVELTIME, IN MICROSECONDS

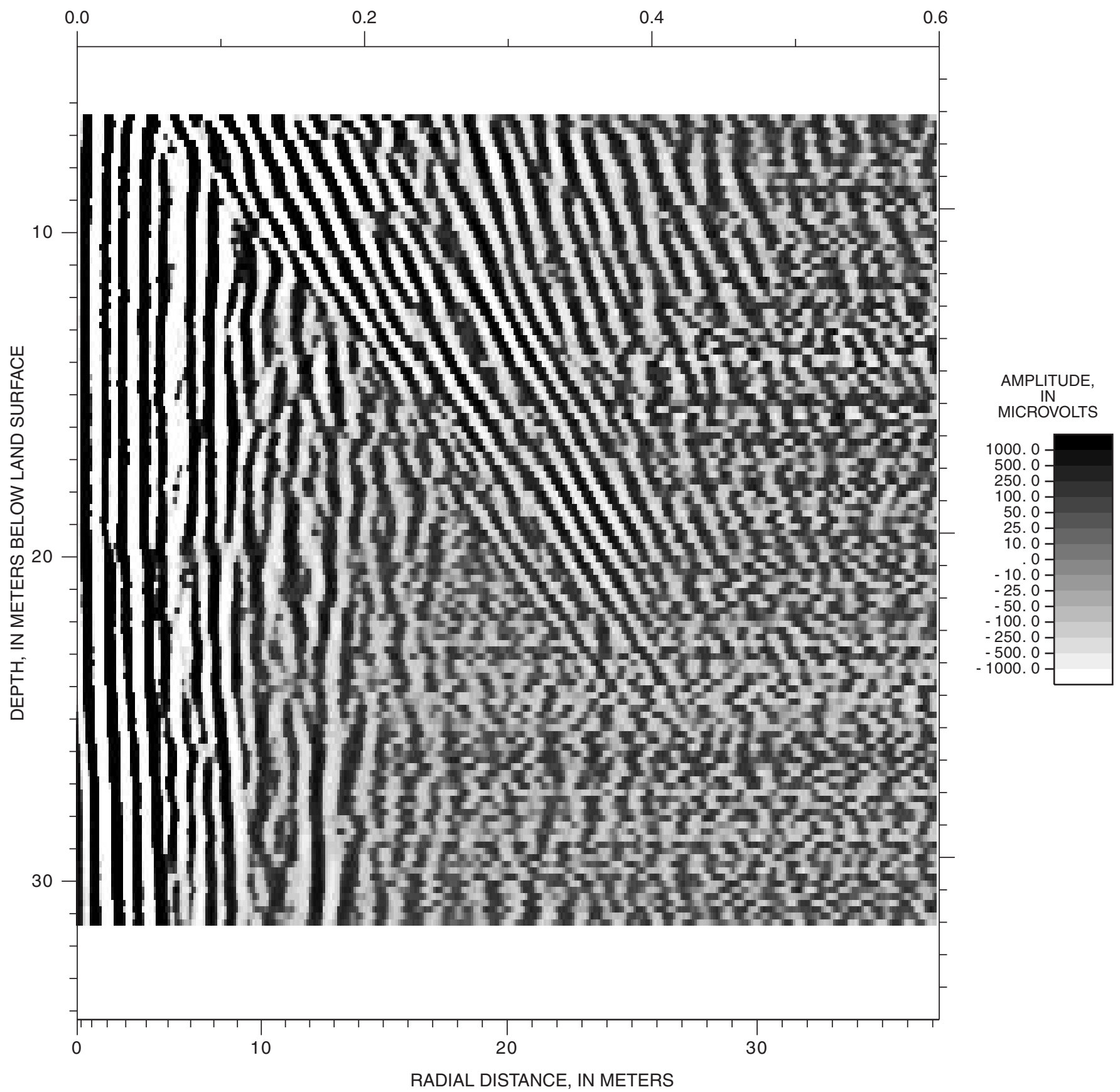

Figure 11. Processed 60-megahertz borehole-radar log from borehole MW09 in Machiasport, Maine. 


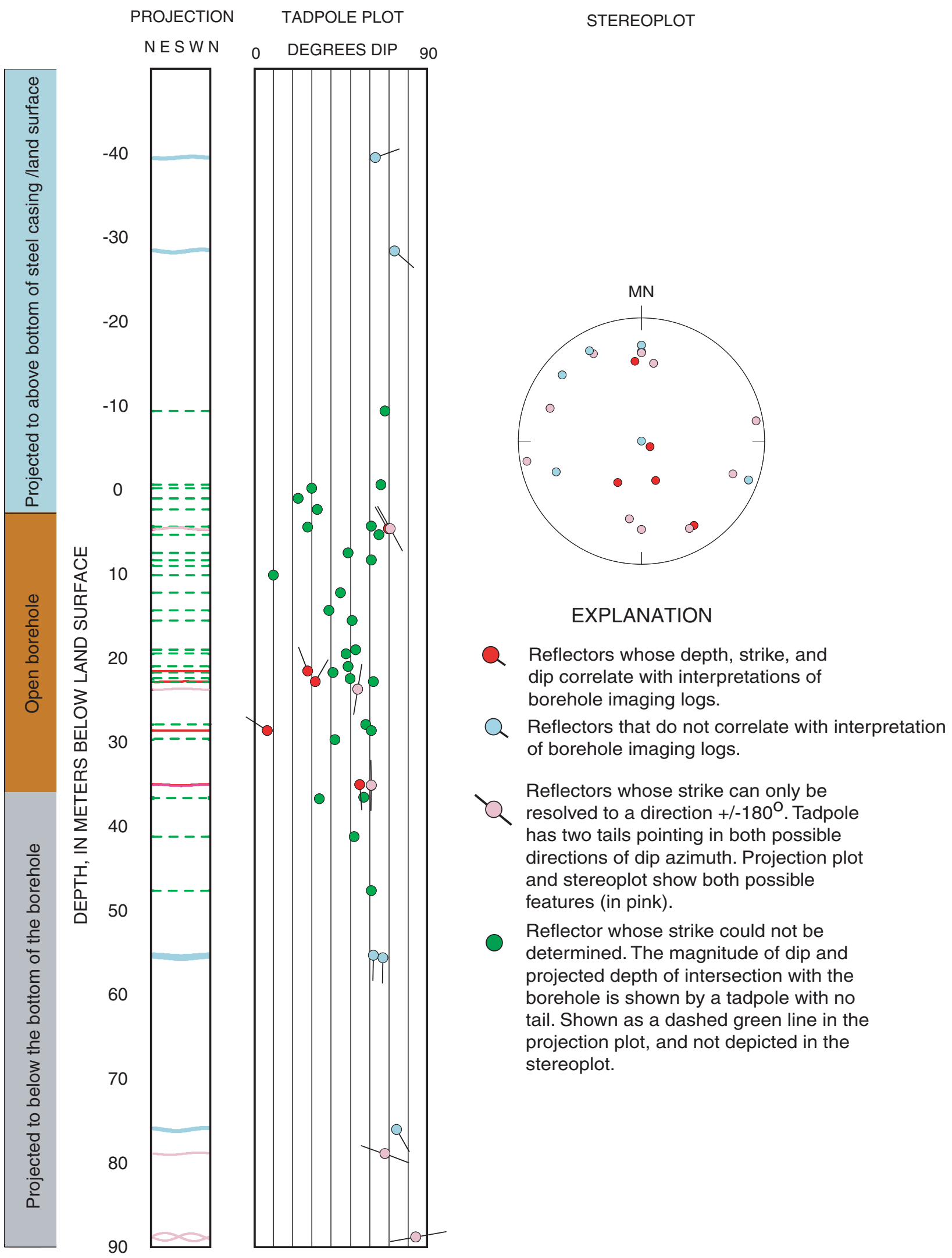

Figure 12. Projection, modified tadpole, and stereoplot for radar reflections identified in borehole MW09 in Machiasport, Maine. All orientations are relative to magnetic north (MN). 


\section{Analysis of Borehole-Radar Reflection Data from Machiasport, Maine, December 2003}

Table 3. Summary of borehole-radar reflector data from borehole MW09 in Machiasport, Maine.

[-- indicates strike could not be determined; NA indicates not applicable]

\begin{tabular}{|c|c|c|c|c|c|c|}
\hline $\begin{array}{l}\text { Projected depth, } \\
\text { in meters below } \\
\text { land surface }{ }^{1}\end{array}$ & Dip azimuth & Strike ${ }^{2}$ & $\mathrm{Dip}^{2}$ & $\begin{array}{l}\text { Continuity factor } \\
\text { (1=very good, } \\
5=\text { poor) }\end{array}$ & $\begin{array}{c}\text { Directional } \\
\text { confidence factor } \\
\text { (1=very good, } 5=\text { poor })\end{array}$ & $\begin{array}{c}\text { Correlated with } \\
\text { borehole } \\
\text { imaging logs }\end{array}$ \\
\hline-139.4 & 290 & 200 & 82 & 4 & 4 & -- \\
\hline-39.6 & 70 & 340 & 63 & 3 & 5 & -- \\
\hline-28.5 & 130 & 40 & 73 & 4 & 3 & -- \\
\hline-9.5 & -- & -- & 68 & 3 & NA & -- \\
\hline-0.7 & -- & -- & 66 & 3 & NA & -- \\
\hline-0.3 & -- & -- & 30 & 1 & NA & -- \\
\hline 0.9 & -- & -- & 23 & 2 & NA & -- \\
\hline 2.2 & -- & -- & 33 & 3 & NA & -- \\
\hline 4.2 & -- & -- & 61 & 2 & NA & -- \\
\hline 4.3 & -- & -- & 28 & 3 & NA & -- \\
\hline 4.5 & 328 & 238 & 70 & 5 & 5 & yes \\
\hline 4.5 & 331 & 241 & 70 & 5 & 4 & -- \\
\hline 5.2 & -- & -- & 65 & 2 & NA & -- \\
\hline 7.4 & -- & -- & 49 & 2 & NA & -- \\
\hline 8.2 & -- & -- & 61 & 1 & NA & -- \\
\hline 8.9 & -- & -- & 59 & 2 & NA & -- \\
\hline 10.0 & -- & -- & 10 & 4 & NA & -- \\
\hline 12.1 & -- & -- & 45 & 2 & NA & -- \\
\hline 14.2 & -- & -- & 39 & 4 & NA & -- \\
\hline 15.4 & -- & -- & 51 & 3 & NA & -- \\
\hline 18.9 & -- & -- & 53 & 4 & NA & -- \\
\hline 19.4 & -- & -- & 48 & 2 & NA & -- \\
\hline 20.9 & -- & -- & 49 & 2 & NA & -- \\
\hline 21.4 & 340 & 250 & 28 & 4 & 5 & yes \\
\hline 21.6 & -- & -- & 41 & 2 & NA & -- \\
\hline 22.3 & -- & -- & 50 & 2 & NA & -- \\
\hline 22.7 & 30 & 300 & 32 & 4 & 4 & yes \\
\hline 22.7 & -- & -- & 62 & 4 & NA & -- \\
\hline 23.6 & 9 & 279 & 54 & 5 & 5 & -- \\
\hline 23.6 & -- & -- & 53 & 2 & NA & -- \\
\hline 27.8 & -- & -- & 58 & 2 & NA & -- \\
\hline 28.5 & 303 & 213 & 7 & 4 & 4 & yes \\
\hline 28.5 & -- & -- & 61 & 2 & NA & -- \\
\hline 29.6 & -- & -- & 42 & 2 & NA & -- \\
\hline 34.9 & 175 & 85 & 55 & 4 & 4 & yes \\
\hline 35.0 & 180 & 90 & 61 & 4 & 5 & -- \\
\hline 36.4 & -- & -- & 57 & 3 & NA & -- \\
\hline 36.6 & -- & -- & 34 & 3 & NA & -- \\
\hline 41.1 & -- & -- & 52 & 2 & NA & -- \\
\hline 47.5 & -- & -- & 61 & 3 & NA & -- \\
\hline 55.2 & 180 & 90 & 62 & 4 & 3 & -- \\
\hline 55.5 & 180 & 90 & 67 & 4 & 4 & -- \\
\hline 75.9 & 150 & 60 & 74 & 3 & 2 & -- \\
\hline 78.8 & ${ }^{4} 150 / 330$ & ${ }^{4} 60 / 240$ & 68 & 3 & 5 & -- \\
\hline 88.7 & ${ }^{4} 260 / 80$ & ${ }^{4} 170 / 350$ & 84 & 2 & 5 & -- \\
\hline
\end{tabular}

${ }^{1}$ Reflectors with a negative depth are projected above land surface.

${ }^{2}$ Strike and dip are presented in the right-hand rule where the strike is in degrees east of magnetic north and the dip direction is to the right of the strike.

${ }^{3}$ Reflectors that can be correlated with features identified in the acoustic or optical televiewer logs are indicated with "yes."

${ }^{4}$ Strike and dip azimuth cannot be uniquely determined from the data and is shown $\pm 180^{\circ}$. 


\section{Borehole MW10}

Location and construction. Borehole MW10 is located south of the top of Howard Mountain near the FAA dome and within the footprint of the former Building 114 (Thompson and others, 2005). This borehole contained water with measurable TCE concentrations, which are thought to be from the source area in Building 114 (Weston Solutions, 2003). An exposed bedrock cliff is about 10 to $15 \mathrm{~m}$ east-northeast and wraps around to about $100 \mathrm{~m}$ south-southeast of MW10. On the eastnortheast side, the cliff extends downward a vertical distance of about $20 \mathrm{~m}$ over a lateral distance of about $20 \mathrm{~m}$. Fractures observed in the outcrop making up the bedrock cliff were parallel to the major fault zone in the area, which strikes northwest to the southeast. Another set of nearly vertical fractures strikes normal to the fault zone. In addition, several sheeting fractures that are nearly parallel to the land surface impart a stair-step shape on the cliff face (James Vernon, ENSR International, written commun., 2005).

In June 2003, MW10 was drilled with air hammer rotary methods, and steel casing was set to $5.79 \mathrm{~m}$ below land surface to prevent flow between the unconsolidated sediments and the bedrock. Below the steel casing, MW10 is a $10-\mathrm{cm}$-diameter open hole for a total depth of $60.15 \mathrm{~m}$ below land surface. MW10 deviates gradually about 3 m towards the east, over the entire length of the borehole (fig. 13). Borehole-radar data were collected relative to top of casing and were corrected in post processing to land surface, which is $0.81 \mathrm{~m}$ below the top of steel casing. All radar reflector depths are reported relative to land surface.

The open-hole ambient water level was about $37.03 \mathrm{~m}$ below the land surface on December 10, 2003. The water level has been consistently low since MW10 was drilled. Because of the substantial depth to water and the amount of open hole above the water table, the VRP analyses were conducted above and below the water level. The radar-wave velocity of the zone above the water level was $125 \mathrm{~m} / \mu \mathrm{s}$; the velocity of the zone below the water level was $124 \mathrm{~m} / \mu \mathrm{s}$. For the interpretation of reflectors in this borehole, a uniform velocity of $125 \mathrm{~m} / \mu \mathrm{s}$ was used.

Lithologic and fracture characterization. MW10 intersects flow-banded stony rhyolite with possible autobreccia. Because the ATV tool has to be submerged in fluid, the ATV data are limited to the bottom of the borehole below a depth of about $37 \mathrm{~m}$. Fracture interpretations above the water table were limited to OTV data. The fractures identified in the ATV and OTV data showed some very steeply dipping features (table 4). Stereoplots show some clustering of the poles to fracture planes (fig. 14). Using the fracture interpretations of Weston Solutions (2003), the stereoplots indicate the possibility of multiple fracture zones. One cluster of poles to planes near the left edge of the stereoplot represents reflectors that dip steeply $\left(60^{\circ}\right.$ to $80^{\circ}$ from horizontal) towards the east-northeast. The cluster of poles to planes near the bottom edge of the stereoplot diagram represents planes that dip steeply $\left(70^{\circ}\right.$ to $\left.85^{\circ}\right)$ to the north and northnortheast. Two smaller clusters of poles to planes, near the top and right sides of the diagram, represent features that dip steeply (approximately $70^{\circ}$ to $85^{\circ}$ degrees from horizontal) to the south-southeast and west-southwest. A few poles to planes plot near the center of the stereoplot, indicating nearly horizontal features. The fracture at $46.8 \mathrm{~m}$, which was identified as transmissive by heat-pulse flowmeter logging, is nearly horizontal.

Velocity and radial penetration distance in MW10. VRP analyses indicated that a uniform velocity of $125 \mathrm{~m} / \mu \mathrm{s}$ could be used for analyses over the entire length of borehole MW10. In addition, the depths of penetration were uniform above and below the water table. The radial penetration distance with the directional tool was $40 \mathrm{~m}$. The penetration distance with the non-directional tool was $30 \mathrm{~m}$ from the borehole. Both are near the end of the data-acquisition time window, which means that if the time window were increased, it may have provided a deeper view into the formation; however, the strength of the reflectors appeared to be diminishing within the time window that was used.

The radargram for MW10 shows a small sample shift in the data at the depth of the water table, at about $43 \mathrm{~m}$ (fig. 15). The sample shift is related to the lower velocity and saturation conditions in the bottom of the borehole. 


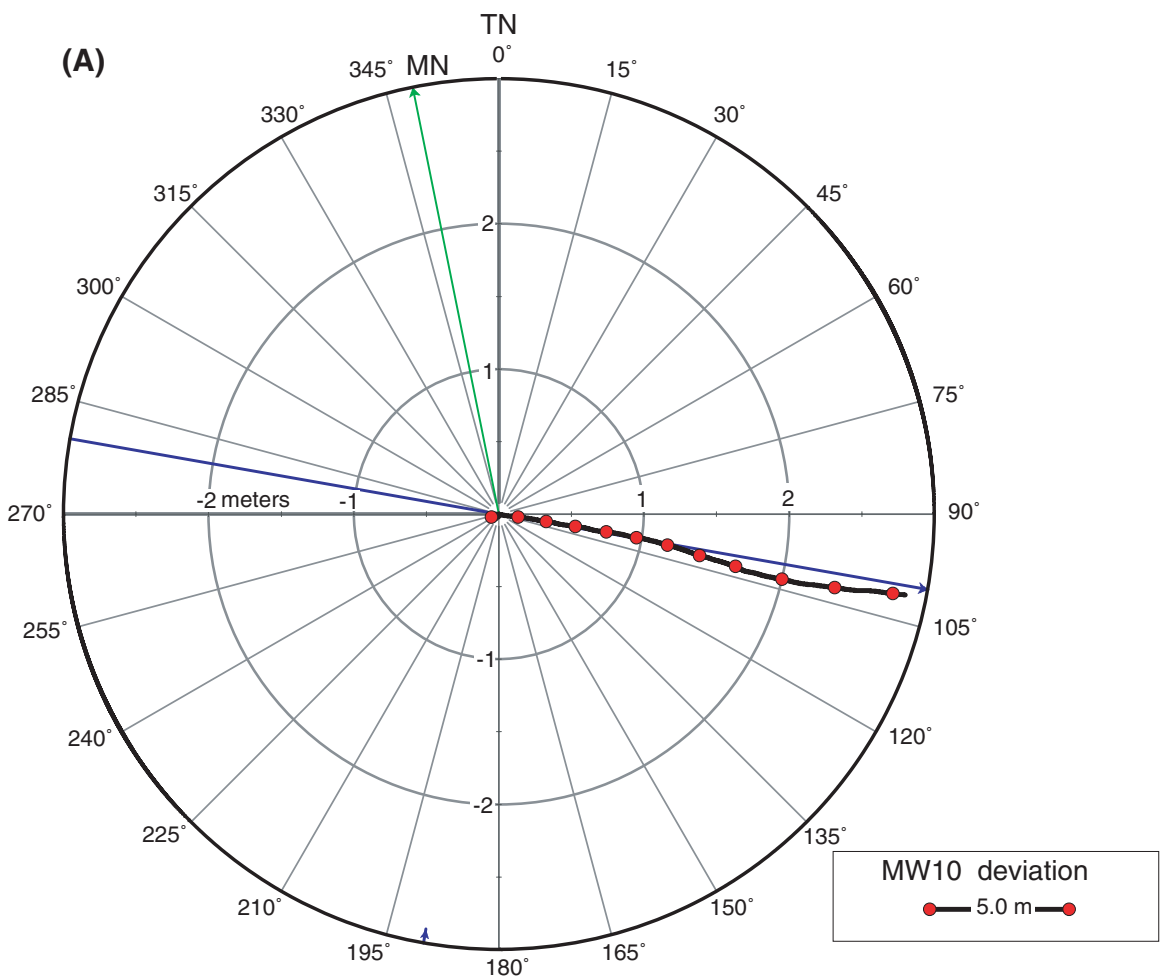

(B)

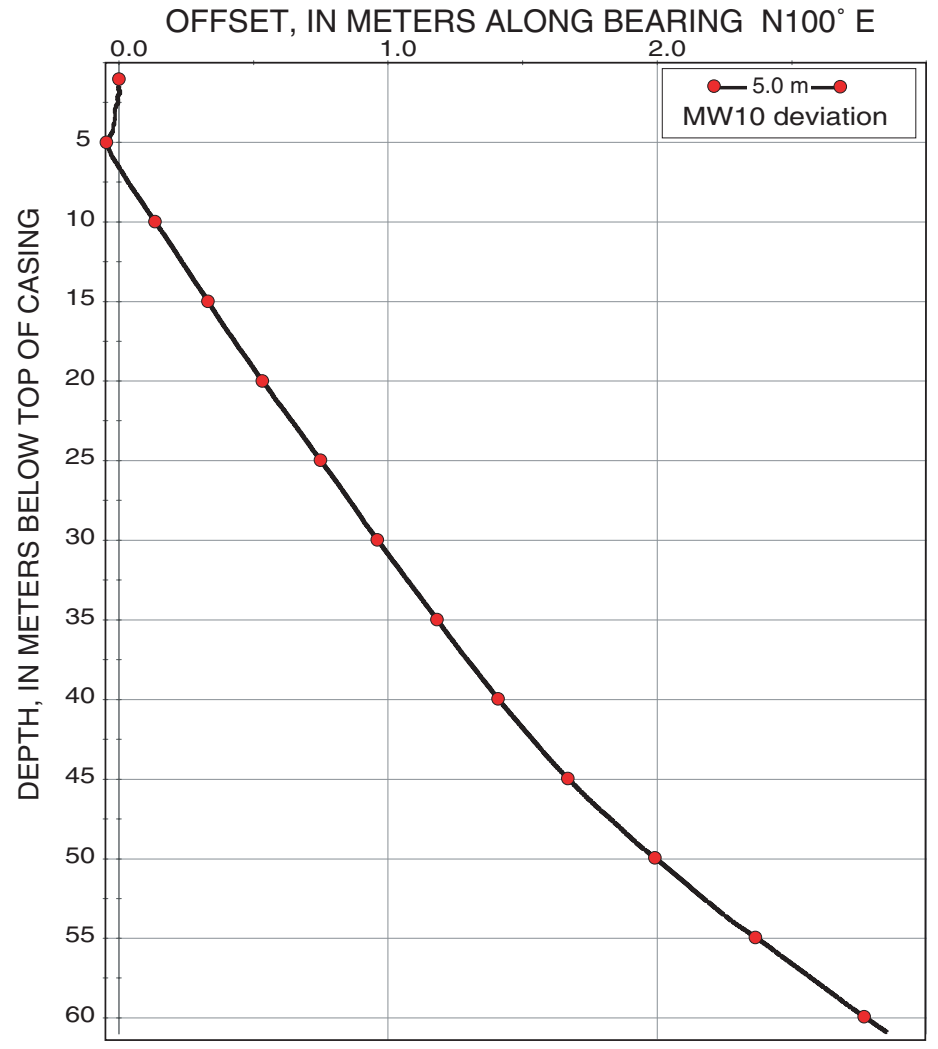

Figure 13. Borehole deviation logs for borehole MW10 in Machiasport, Maine. (A) Radial deviation plot in 5-meter depth increments. (B) Cross-sectional view of borehole deviation in meters along a bearing of $N 100^{\circ} \mathrm{E}$, which is shown as a blue line in the radial plot. [TN, true north; MN magnetic north] 


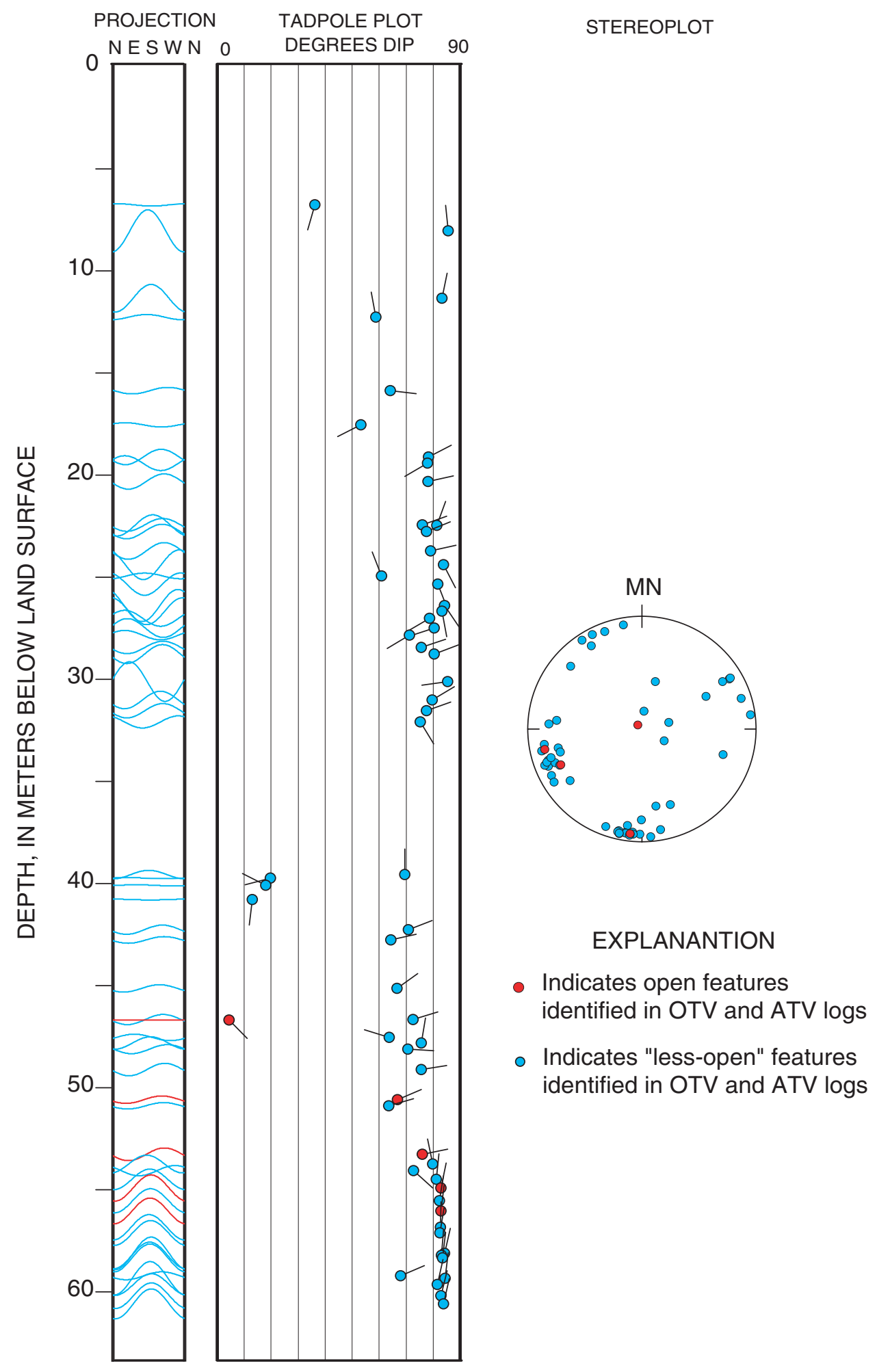

Figure 14. Projection, tadpole, and stereoplot for optical televiewer (OTV) and acoustic televiewer (ATV) data collected in borehole MW10 in Machiasport, Maine. OTV results were used above 37 meters, and ATV results were used below 37 meters. All orientations are relative to magnetic north (MN). 
Table 4. Summary of optical and acoustic televiewer data from borehole MW10 in Machiasport, Maine.

[Data modified and reinterpreted from Weston Solutions, 2003]

\begin{tabular}{|c|c|c|c|c|}
\hline $\begin{array}{l}\text { Depth, in meters } \\
\text { below land surface }\end{array}$ & Dip azimuth & Strike ${ }^{1}$ & $\operatorname{Dip}^{1}$ & Description \\
\hline 6.9 & 196 & 106 & 36 & less-open feature \\
\hline 8.1 & 355 & 265 & 86 & less-open feature \\
\hline 11.4 & 12 & 282 & 83 & less-open feature \\
\hline 12.3 & 350 & 260 & 59 & less-open feature \\
\hline 16.0 & 96 & 6 & 64 & less-open feature \\
\hline 17.6 & 243 & 153 & 53 & less-open feature \\
\hline 19.2 & 62 & 332 & 78 & less-open feature \\
\hline 19.5 & 240 & 150 & 78 & less-open feature \\
\hline 20.4 & 77 & 347 & 78 & less-open feature \\
\hline 22.5 & 70 & 340 & 76 & less-open feature \\
\hline 22.5 & 20 & 290 & 81 & less-open feature \\
\hline 22.8 & 68 & 338 & 78 & less-open feature \\
\hline 23.8 & 77 & 347 & 79 & less-open feature \\
\hline 24.5 & 153 & 63 & 84 & less-open feature \\
\hline 25.0 & 340 & 250 & 61 & less-open feature \\
\hline 25.4 & 159 & 69 & 82 & less-open feature \\
\hline 26.5 & 146 & 56 & 84 & less-open feature \\
\hline 26.7 & 170 & 80 & 83 & less-open feature \\
\hline 27.1 & 240 & 150 & 79 & less-open feature \\
\hline 27.6 & 252 & 162 & 80 & less-open feature \\
\hline 27.9 & 239 & 149 & 71 & less-open feature \\
\hline 28.5 & 71 & 341 & 76 & less-open feature \\
\hline 28.9 & 69 & 339 & 81 & less-open feature \\
\hline 30.2 & 262 & 172 & 85 & less-open feature \\
\hline 31.1 & 58 & 328 & 80 & less-open feature \\
\hline 31.6 & 70 & 340 & 78 & less-open feature \\
\hline 32.2 & 149 & 59 & 75 & less-open feature \\
\hline 39.7 & 0 & 270 & 70 & less-open feature \\
\hline 39.8 & 256 & 166 & 20 & less-open feature \\
\hline 40.2 & 298 & 208 & 18 & less-open feature \\
\hline 40.9 & 187 & 97 & 13 & less-open feature \\
\hline 42.4 & 68 & 338 & 71 & less-open feature \\
\hline 42.8 & 77 & 347 & 65 & less-open feature \\
\hline 45.2 & 54 & 324 & 67 & less-open feature \\
\hline 46.7 & 72 & 342 & 73 & less-open feature \\
\hline 46.8 & 135 & 45 & 4 & open feature \\
\hline 47.6 & 288 & 198 & 64 & less-open feature \\
\hline 47.9 & 9 & 279 & 76 & less-open feature \\
\hline 48.2 & 93 & 3 & 71 & less-open feature \\
\hline 49.2 & 81 & 351 & 76 & less-open feature \\
\hline 50.7 & 66 & 336 & 67 & open feature \\
\hline 51.0 & 74 & 344 & 64 & less-open feature \\
\hline 53.4 & 78 & 348 & 76 & open feature \\
\hline 53.8 & 349 & 259 & 80 & less-open feature \\
\hline 54.1 & 132 & 42 & 73 & less-open feature \\
\hline 54.6 & 5 & 275 & 81 & less-open feature \\
\hline
\end{tabular}


Table 4. Summary of optical and acoustic televiewer data from borehole MW10 in Machiasport, Maine.-Continued

[Data modified and reinterpreted from Weston Solutions, 2003]

\begin{tabular}{cclll}
\hline $\begin{array}{c}\text { Depth, in meters } \\
\text { below land surface }\end{array}$ & Dip azimuth & Strike $^{1}$ & Dip $^{1}$ & \multicolumn{1}{c}{ Description } \\
\hline 55.0 & 11 & 281 & 83 & open feature \\
55.6 & 9 & 279 & 83 & less-open feature \\
56.1 & 6 & 276 & 83 & open feature \\
56.9 & 1 & 271 & 83 & less-open feature \\
57.2 & 9 & 279 & 83 & less-open feature \\
58.2 & 12 & 282 & 84 & less-open feature \\
58.3 & 5 & 275 & 83 & less-open feature \\
58.4 & 6 & 276 & 64 & less-open feature \\
59.3 & 66 & 336 & 85 & less-open feature \\
59.4 & 7 & 277 & 82 & less-open feature \\
59.7 & 13 & 283 & 83 & less-open feature \\
60.3 & 13 & 283 & less-open feature \\
60.7 & 12 & 282 & less-open feature \\
\hline
\end{tabular}

${ }^{1}$ Strike and dip are presented in the right-hand rule where the strike is in degrees east of magnetic north and the dip direction is to the right of the strike. 


\section{Analysis of Borehole-Radar Reflection Data from Machiasport, Maine, December 2003}

Borehole-radar reflectors in MW10. The most prominent and unusual feature in the radar record for MW10 (fig. 15) is a slightly curved feature observed over the entire depth of the borehole. It is located about $10 \mathrm{~m}$ from the borehole near the top of the borehole and about $20 \mathrm{~m}$ near the bottom of the borehole. This feature roughly coincides with the location of the rock cliff face. No other reflectors break this reflector, indicating it is a very strong reflector. A plane cannot be fit to the feature because it is an irregular (non-planar) shape. The interpreted orientation of the reflector parallel to $\mathrm{N} 30^{\circ} \mathrm{E}$ or $\mathrm{N} 210^{\circ} \mathrm{E}$ is consistent with the orientation of the cliff face proximal to the borehole. The cliff face to the south of the borehole also may be visible in the radargram at a distance about $30 \mathrm{~m}$ from the borehole, although this reflector is not as prominent as the reflection off of the cliff face to the east-northeast.

A total of 53 reflectors were interpreted from the boreholeradar reflection data collected in MW10 (table 5). Twenty-four of these reflectors were observed only in the dipole (non-directional) radar data (shown in green, fig. 16). Nine of the 53 reflectors correlate to interpreted features from the ATV logs (shown in red, fig. 16). Ten of the reflectors, which do not correlate with the OTV and ATV, are projected to intersect below the bottom of the borehole, and 14 reflectors are projected to intersect the borehole above the open part of the borehole (in the casing or above the borehole) (fig. 16). Four reflectors had strike values that could be resolved to a bearing $\pm 180^{\circ}$. These reflectors are shown as pink tadpoles with two tails and with both possible poles to the reflection plane in the stereoplot (fig. 16). Although the filtering may have removed many near vertical features from the radargram, several steeply dipping reflectors were identified in the rock surrounding the borehole. These steeply dipping features are consistent with the fracture pattern observed in the borehole-imaging logs, which showed most of the features dipping greater than $70^{\circ}$ from horizontal (Weston Solutions, 2003). The actual reflectors, however, that intersect above or below the open hole could not be observed by the ATV and OTV imaging methods. The distribution of radar reflectors, as displayed on the projection and tadpole plots, indicates there is a fairly uniform distribution of reflectors over the open part of the borehole. Also, most of the tadpoles are on the right side of the tadpole plot, indicating that many of the reflectors dip at angles greater than $50^{\circ}$ from horizontal.

Logging with the heat-pulse flowmeter under pumping conditions indicated that most inflow to borehole MW10 occurs between 44.8 and $48.2 \mathrm{~m}$ below land surface, probably from the prominent fractures at about $46.7 \mathrm{~m}$ below land surface. One of the fractures at $46.8 \mathrm{~m}$ below land surface was nearly horizontal, and the other at $46.7 \mathrm{~m}$ below land surface was nearly vertical (striking $\mathrm{N} 342^{\circ} \mathrm{E}$, dipping $73^{\circ} \mathrm{NE}$ ). A radar reflector was identified at $46.0 \mathrm{~m}$ below land surface, but the strike and dip of the radar reflector $\left(\mathrm{N} 252^{\circ} \mathrm{E}, 41^{\circ} \mathrm{N}\right)$ differ from both the nearly horizontal and the nearly vertical features observed in the borehole-image logs at that depth. A shallow, dipping reflector (at $25^{\circ}$ from horizontal) was identified at a depth of $48.3 \mathrm{~m}$ below land surface, but the strike of the feature could not be resolved. Another weak inflow zone detected from 49.7 to $53.3 \mathrm{~m}$ below land surface might be attributed to any one of the four fractures identified in the ATV log over that depth range. The radar data showed three reflectors over that depth range; however, only one reflector at a depth of $49.7 \mathrm{~m}$ below land surface could be resolved in both strike and dip. The orientation of the radar reflector is $\mathrm{N} 229^{\circ} \mathrm{E}, 59^{\circ} \mathrm{NW}$, whereas all four features identified in the ATV $\log$ were about $\mathrm{N} 340^{\circ} \mathrm{E}, 68^{\circ} \mathrm{NE}$. Although the dip and the depth of these features have good agreement, the strike differs by nearly $90^{\circ}$, which may indicate that the two methods did not see the same feature.

A radar reflector does not necessarily indicate a transmissive fracture. Reflections can also be the result of fluid- or airfilled fractures, changes in rock type, and (or) flow-banding fabric within the volcanic rocks. The strongest reflections are produced at the interface of materials with highly contrasting electromagnetic properties, such as rock to fluid- or air-filled fracture and rock to air. In addition, not all fractures identified in imaging logs and flowmeter logs as transmissive are detected with borehole radar. This could be caused by interference with other reflectors and (or) insufficient contrasts to resolve a small aperture fracture.

In general, borehole imaging and radar-reflection logging indicate that the fracture network comprises many steeply dipping fractures that strike and dip in many directions. The poles to planes of reflectors observed in MW10 show a wide variation in strike and dip. The stereoplot for the fractures intersecting the borehole showed more clustering in strike than the stereoplot for the radar reflectors. This may be because the borehole imaging tools allow for high-resolution sampling over very short distances where properties of the aquifer tend to be similar or more spatially correlated. Because borehole radar penetrates into the aquifer, it potentially can map more variability over a larger sampling volume. 
TWO-WAY TRAVELTIME, IN MICROSECONDS

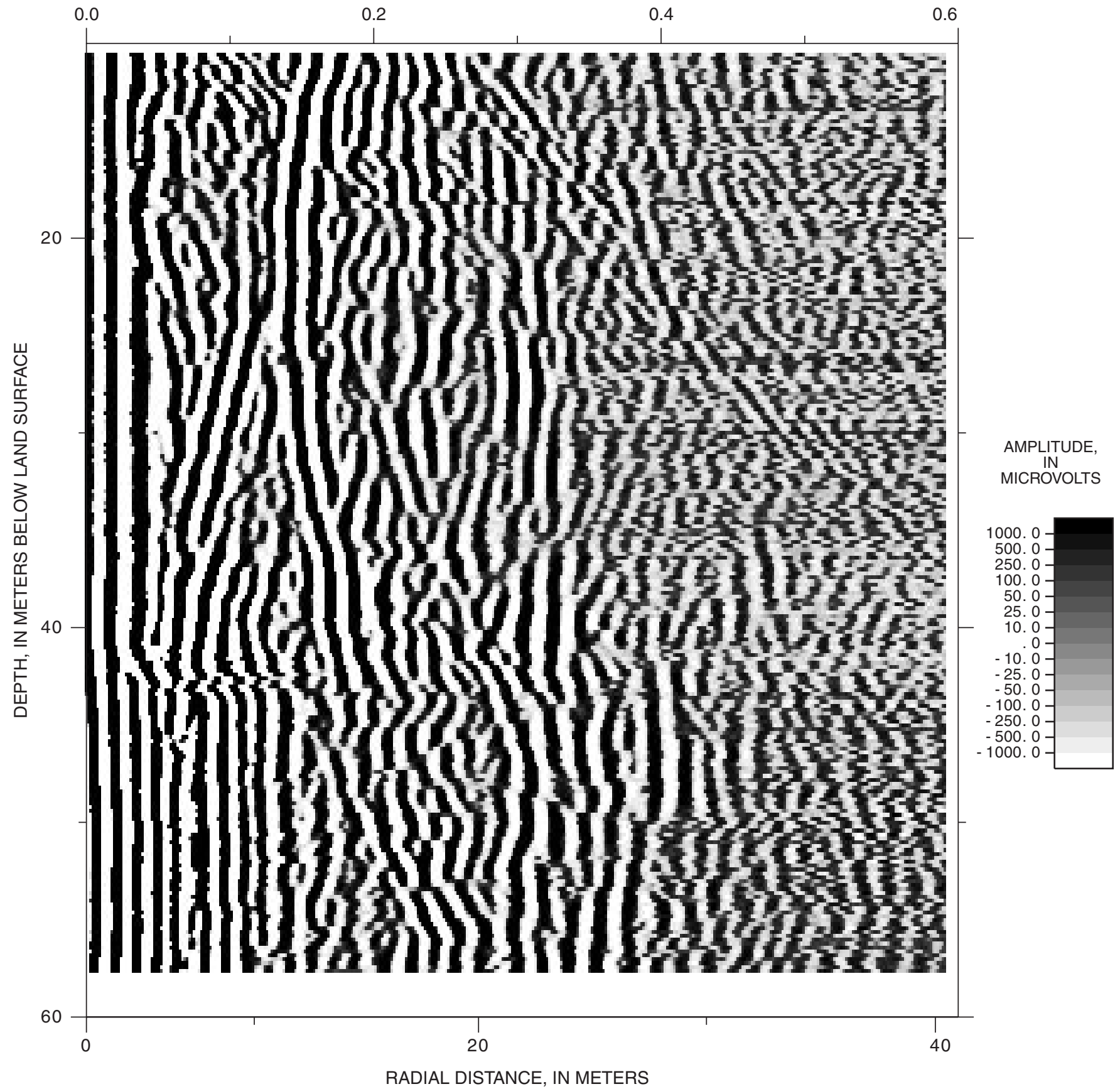

Figure 15. Processed 60-megahertz borehole-radar log from borehole MW10 in Machiasport, Maine. 


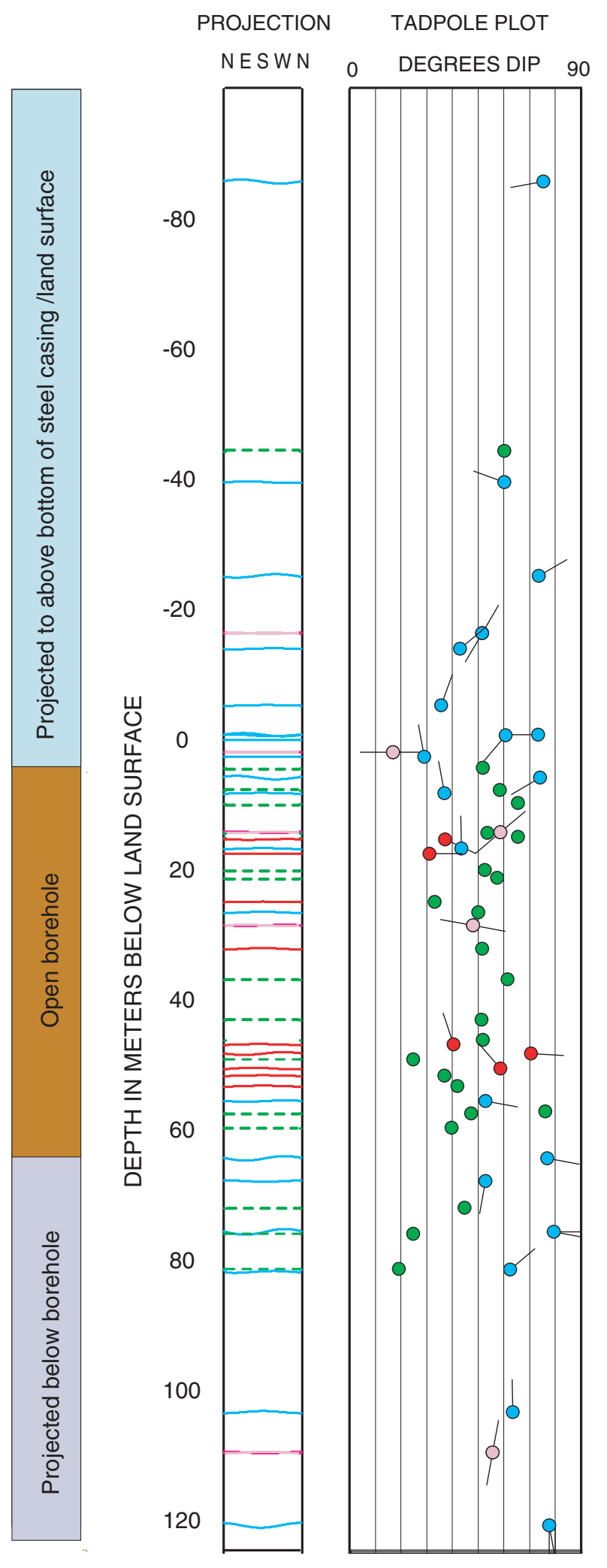

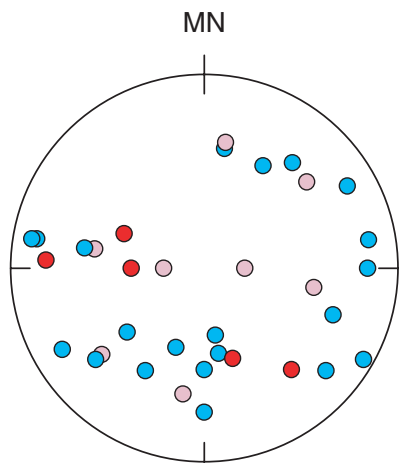

EXPLANATION

Reflectors whose depth, strike, and dip correlate with interpretations of borehole imaging logs.

Q Reflectors that do not correlate with interpretation of borehole imaging logs.

Reflectors whose strike can only be resolved to a direction $+/-180^{\circ}$. Tadole has two tails pointing in both possible directions of dip azimuth. Projection plot and stereoplot show both possible features (in pink).

Reflector whose strike could not be determined. The magnitude of dip and projected depth of intersection with the borehole is shown by a tadpole with no tail. Shown as a dashed green line in the projection plot, and not depicted in the stereoplot.

Figure 16. Projection, modified tadpole, and stereoplot for radar reflections identified in borehole MW10 in Machiasport, Maine. All orientations are relative to magnetic north (MN). 
Table 5. Summary of borehole-radar reflector data from borehole MW10 in Machiasport, Maine.

[-- indicates strike could not be determined, NA indicates not applicable]

\begin{tabular}{|c|c|c|c|c|c|c|}
\hline $\begin{array}{l}\text { Projected depth, } \\
\text { in meters below } \\
\text { land surface }^{1}\end{array}$ & Dip azimuth & Strike ${ }^{2}$ & $\operatorname{Dip}^{2}$ & $\begin{array}{l}\text { Continuity factor } \\
\text { (1=very good, } \\
5=\text { poor) }\end{array}$ & $\begin{array}{c}\text { Directional } \\
\text { confidence factor } \\
(1=\text { very good, } 5=\text { poor })\end{array}$ & $\begin{array}{c}\text { Correlated with } \\
\text { borehole } \\
\text { imaging logs }\end{array}$ \\
\hline-193.1 & 300 & 210 & 85 & 3 & 3 & -- \\
\hline-86.6 & 260 & 170 & 76 & 2 & 2 & -- \\
\hline-45.2 & -- & -- & 60 & 3 & NA & -- \\
\hline-17.2 & $4_{30 / 210}$ & ${ }^{4} 300 / 120$ & 52 & 2 & 5 & -- \\
\hline-14.8 & 50 & 320 & 43 & 2 & 4 & -- \\
\hline-6.1 & 20 & 290 & 36 & 3 & 2 & -- \\
\hline-1.6 & 270 & 180 & 73 & 2 & 4 & -- \\
\hline-1.5 & 220 & 130 & 61 & 4 & 3 & -- \\
\hline 6.9 & -- & -- & 59 & 3 & NA & -- \\
\hline 7.4 & 350 & 260 & 37 & 3 & 4 & -- \\
\hline 8.9 & -- & -- & 66 & 3 & NA & -- \\
\hline 13.4 & ${ }^{4} 230 / 50$ & ${ }^{4} 140 / 320$ & 59 & 3 & 5 & -- \\
\hline 13.5 & -- & -- & 54 & 2 & NA & -- \\
\hline 14.1 & -- & -- & 66 & 2 & NA & -- \\
\hline 14.5 & 114 & 24 & 37 & 5 & 4 & yes \\
\hline 15.9 & 0 & 270 & 44 & 4 & 4 & -- \\
\hline 16.7 & -- & -- & 31 & 4 & NA & yes \\
\hline 19.2 & -- & -- & 53 & 3 & NA & -- \\
\hline 45.3 & -- & -- & 52 & 2 & NA & -- \\
\hline 46.0 & 342 & 252 & 41 & 4 & 5 & yes \\
\hline 47.4 & 93 & 3 & 71 & 4 & 5 & yes \\
\hline 48.3 & -- & -- & 25 & 3 & NA & -- \\
\hline 49.7 & 319 & 229 & 59 & 3 & 3 & yes \\
\hline 50.8 & -- & -- & 37 & 3 & NA & yes \\
\hline 52.4 & -- & -- & 42 & 4 & NA & yes \\
\hline 54.7 & 100 & 10 & 53 & 3 & 5 & -- \\
\hline 56.3 & -- & -- & 76 & 2 & NA & -- \\
\hline 56.6 & -- & -- & 48 & 3 & NA & -- \\
\hline 58.8 & -- & -- & 40 & 4 & NA & -- \\
\hline 63.5 & 100 & 10 & 77 & 2 & 4 & -- \\
\hline 67.0 & 190 & 100 & 53 & 4 & 4 & -- \\
\hline 71.1 & -- & -- & 45 & 3 & NA & -- \\
\hline 74.8 & 100 & 10 & 80 & 2 & 4 & -- \\
\hline 75.1 & -- & -- & 25 & 2 & NA & -- \\
\hline 80.5 & -- & -- & 19 & 2 & NA & -- \\
\hline 80.6 & 50 & 320 & 63 & 3 & 3 & -- \\
\hline
\end{tabular}


Table 5. Summary of borehole-radar reflector data from borehole MW10 in Machiasport, Maine.-Continued

[-- indicates strike could not be determined, NA indicates not applicable]

\begin{tabular}{|c|c|c|c|c|c|c|}
\hline $\begin{array}{l}\text { Projected depth, } \\
\text { in meters below } \\
\text { land surface }\end{array}$ & Dip azimuth & Strike $^{2}$ & $\mathrm{Dip}^{2}$ & $\begin{array}{l}\text { Continuity factor } \\
\text { (1=very good, } \\
5=\text { poor })\end{array}$ & $\begin{array}{c}\text { Directional } \\
\text { confidence factor } \\
\text { (1=very good, } 5=\text { poor })\end{array}$ & $\begin{array}{l}\text { Correlated with } \\
\text { borehole } \\
\text { imaging logs }\end{array}$ \\
\hline 102.5 & 0 & 270 & 64 & 4 & 3 & -- \\
\hline 119.9 & 170 & 80 & 78 & 3 & 2 & -- \\
\hline
\end{tabular}

${ }^{1}$ Reflectors with a negative depth are projected above land surface.

${ }^{2}$ Strike and dip are presented in the right-hand rule where the strike is in degrees east of magnetic north and the dip direction is to the right of the strike.

${ }^{3}$ Reflectors that can be correlated with features identified in the acoustic or optical televiewer logs are indicated with "yes."

${ }^{4}$ Strike and dip azimuth cannot be uniquely determined from the data and is shown $\pm 180^{\circ}$.

\section{Results of Borehole Radar Surveys at the Bucks Harbor Site}

Box plots generated for all reflectors whose orientation could be determined in boreholes MW09 and MW10 indicate that the rock is highly fractured. It was difficult, however, to determine an overall pattern of the reflections. Box plots showing the more continuous single-hole borehole-radar reflectors in MW09 and MW10 are shown in figures 17 and 18, respectively. Reflectors that are projected into the open borehole interval are colored yellow. Reflections that project to above the top of casing are colored green, and reflections that could only be resolved to $\pm 180^{\circ}$ are colored red and blue. In MW09, many of the continuous reflectors strike north-south and many of these reflectors are steeply dipping (fig. 17). In MW10, the continuous reflectors strike in numerous directions and have a wide range of dips (fig. 18). There were many more continuous reflectors interpreted from MW10 than from MW09.

For each borehole, radar reflectors whose orientation could be determined were projected to a horizontal plane at the elevation of land surface. Although these fractures are not necessarily this long, they were projected along their orientation to intersect the bedrock surface and land surface. A contaminant originating on or near land surface would infiltrate into the overburden and then would likely enter the fractures. Hence, the projection of these fractures relative to the known contaminant sources provides some insight into the fracture pattern in the subsurface.
Single-hole reflection data for MW09 showed only a few reflectors that project toward Building 501, which is approximately $50 \mathrm{~m}$ northeast of the borehole (fig. 19). The other features observed in the radar log (and the borehole imaging logs) indicate a variety of orientations that project to the northeast, east, and west of the borehole. The borehole-radar data from MW09 indicate that the fracture network is quite complex and interconnected, and not dominated by a single fracture.

For borehole MW10, several reflectors extend toward or are within the footprint of former Building 114, which is the contaminant source location (fig. 20). With the reflectors projected to the land surface (fig. 20), the variable fracture pattern is evident. The high proportion of steeply dipping fractures and the low head in MW10 indicate the possibility for downward fluid and chemical migration in this aquifer. Several reflectors that intersect MW10 are projected to intersect the footprint of the former Building 501 location. These data do not indicate anything about the hydraulic connections of these fractures, which would have to be measured using other techniques such as straddle-packer testing or single or hole-to-hole flowmeter logging. As a result, additional boreholes installed at this site for aquifer characterization and (or) for remediation feasibility studies should be positioned such that they consider hydraulic gradient, source area, and contaminant distribution as well as fracture patterns. 


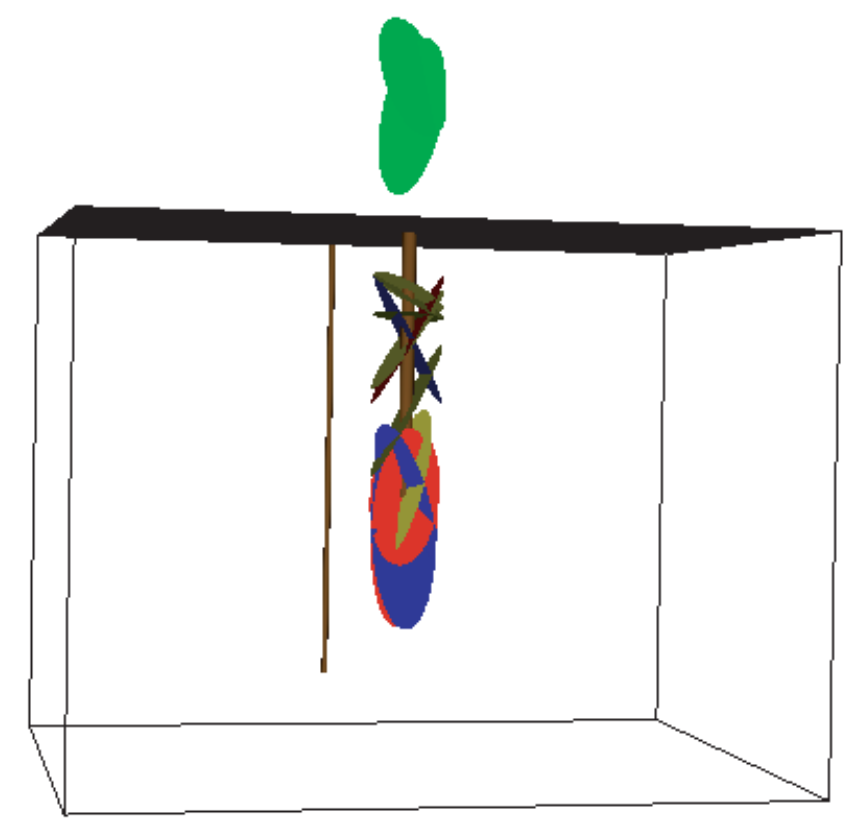

Figure 17. Directional single-hole borehole-radar reflectors with a continuity factor of 1,2,3, or 4 identified from borehole MW09 in Machiasport, Maine. Results are presented in a 3-dimensional box plot viewed from the south. Magnetic north is identified as a brown line on the back side of this figure.

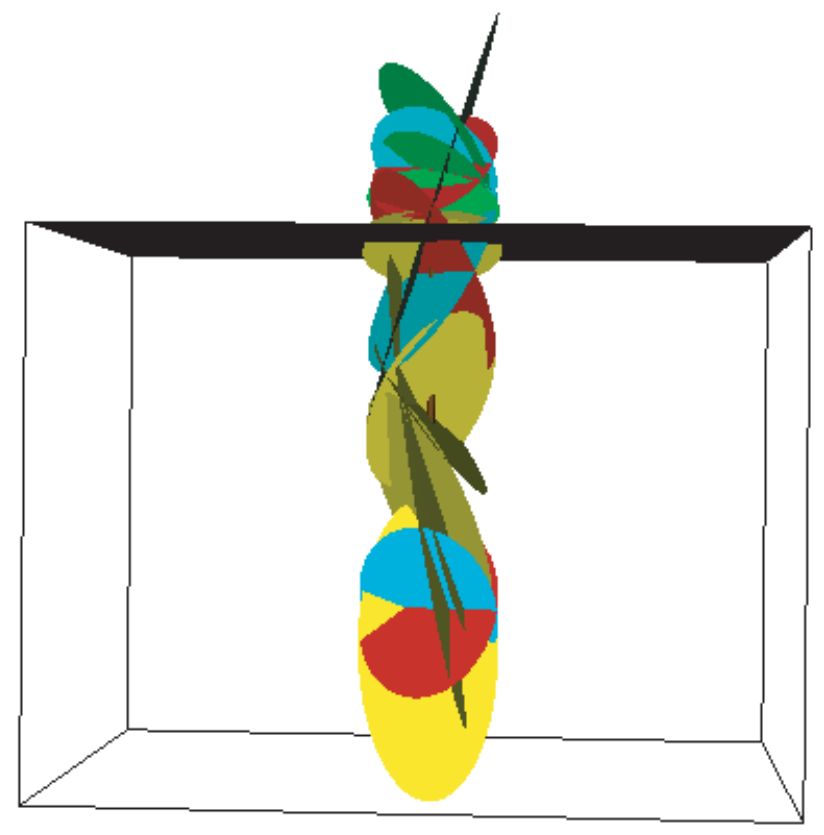

Figure 18. Directional single-hole borehole-radar reflectors with a continuity factor of 1, 2, or 3 identified from borehole MW10 in Machiasport, Maine. Results are presented in a 3-dimensional box plot viewed from the south. 


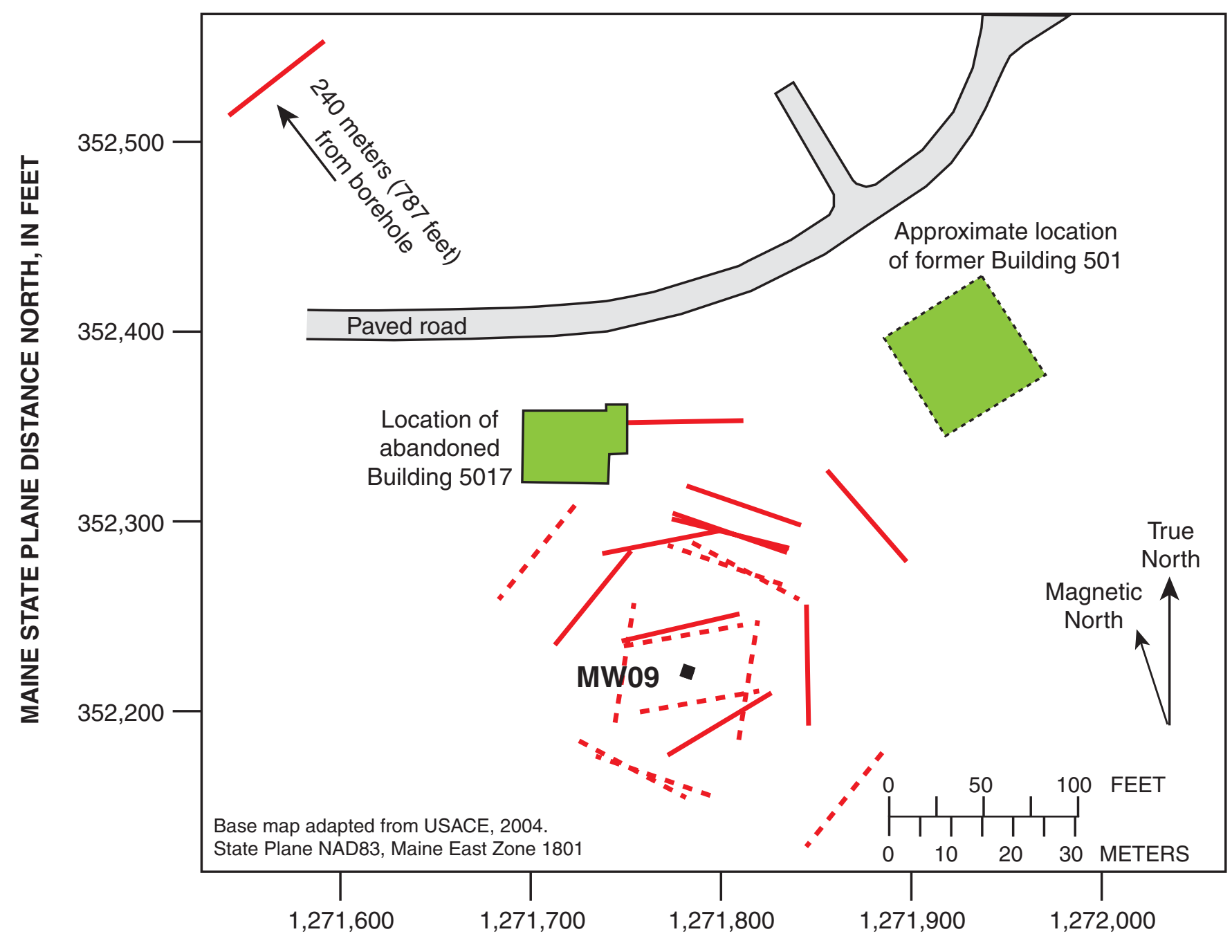

MAINE STATE PLANE DISTANCE EAST, IN FEET

Figure 19. Strike of projected reflectors in borehole-radar logs from borehole MW09 in Machiasport, Maine. Solid lines represent projected reflectors where strike could be determined. Two dashed lines are shown for each of the possible reflectors where the strike could only be resolved in a direction $\pm 180^{\circ}$. The reflectors are projected to a horizontal land surface at the elevation of borehole MW09. The reflectors may not extend to the land surface. Former location of Building 501 is based on foundations mapped by surfacegeophysical methods (Thompson and others, 2005). 


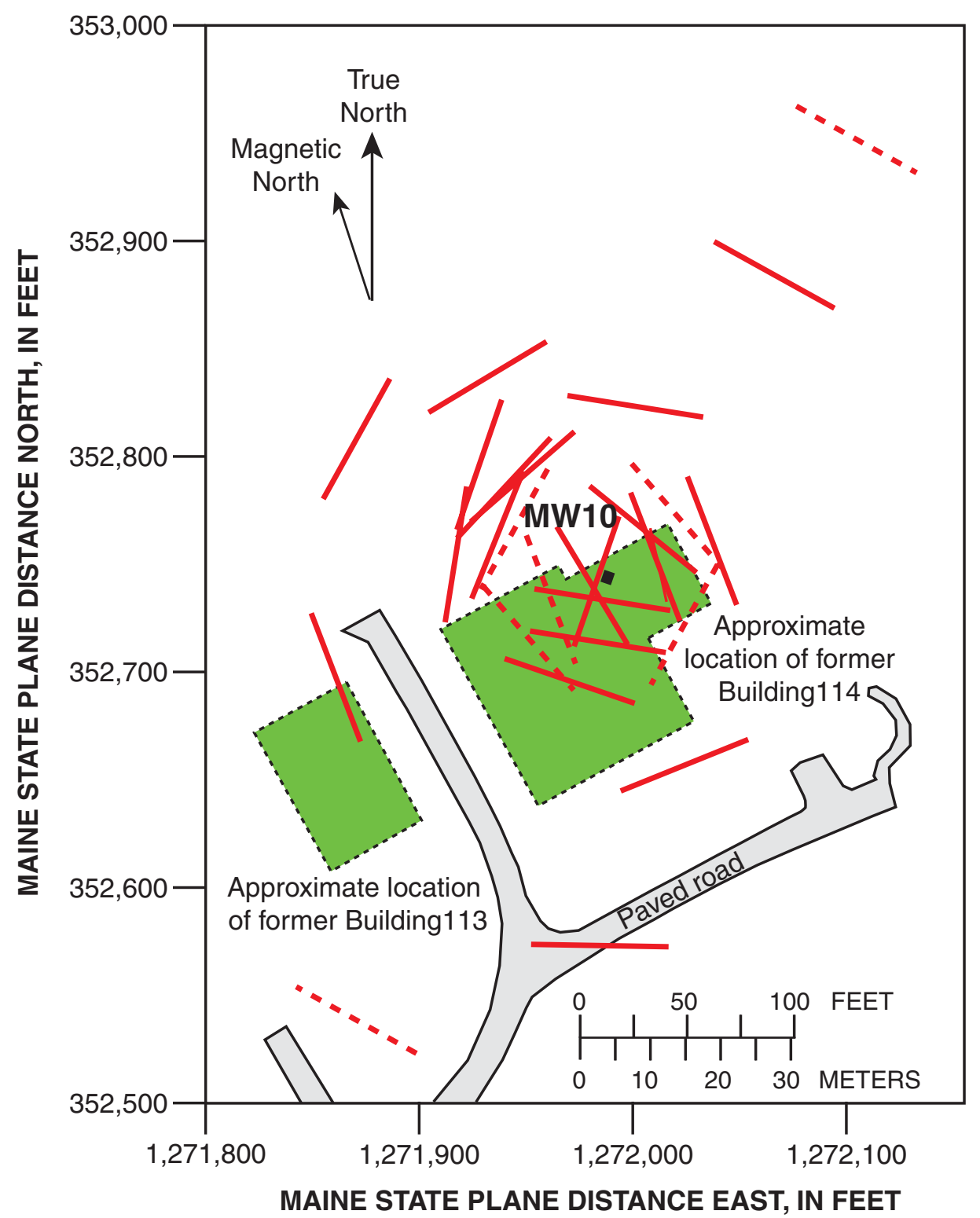

Base map adapted from USACE, 2004. State Plane NAD83, Maine East Zone 1801

Figure 20. Strike of projected reflectors in borehole-radar logs from borehole MW10 in Machiasport, Maine. Solid lines represent projected reflectors where strike could be determined. Two dashed lines are shown for each of the possible reflectors where the strike could only be resolved in a direction $\pm 180^{\circ}$. The reflectors are projected to a horizontal land surface at the elevation of borehole MW10. The reflectors may not extend to the land surface. Building locations are based on foundations mapped by surfacegeophysical methods (Thompson and others, 2005). 


\section{Borehole Spacing for Tomography Surveys and Remediation}

The results of radar surveys in boreholes MW09 and MW10 indicate good depth of radial radar penetration in the rock units on Howard Mountain, suggesting that radar might be a valuable tool for future investigations of the bedrock surrounding the boreholes. The radial penetration results can also be used to estimate a reasonable separation distance between boreholes that would permit hole-to-hole surveys. In radarreflection mode, the EM wave travels to the reflector and back to the receiver. Hence, a radial penetration distance of $20 \mathrm{~m}$ indicates a two-way travel distance of $40 \mathrm{~m}$. For hole-to-hole radar surveys (fig. 2B and 2C), in which the transmitter is in one hole and the receiver is in the other, the EM wave has to travel only one way. Because most raypaths in the tomographic mode (fig. 2C) are longer than the distance between the boreholes, a simple expression can be used to approximate the separation distance of the boreholes.

$$
S=\cos 45^{\circ} \times D,
$$

where

$S \quad$ is the computed distance between the boreholes, and

$D \quad$ is the two-way radial depth of penetration from reflection mode data.

Tomographic data at angles greater than $45^{\circ}$ are often low amplitude, contain noise, and are not used in the data inversion (Day-Lewis and others, 2003). Hence, the $45^{\circ}$-angle constraint is useful for estimating the maximum borehole separation.

For this investigation, the radial depth of penetration was as low as 18 to $22 \mathrm{~m}$ in MW09 and as high as 30 to $40 \mathrm{~m}$ in MW10. The computation for well spacing indicates that boreholes could be spaced about $25 \mathrm{~m}$ apart near MW09 and $40 \mathrm{~m}$ apart near MW10. The penetrations achieved in this investigation, however, were collected in the absence of conductive contaminants, tracers, or remedial measures. In order to accommodate possible changes in fluid electrical properties owing to remediation or a tracer test, a conservative interwell spacing of about $20 \mathrm{~m}$ or less may be appropriate at this site.

For hole-to-hole tomography surveys at this site, the maximum radar response would come from the planar features that are oriented normal to the tomographic plane. For monitoring remediation using borehole radar, boreholes ideally would need to be spaced only $20 \mathrm{~m}$ apart and the tomographic plane would need to include fractures that (1) are transmissive, (2) contain contamination, and (3) are likely have their water chemistry altered by the remediation treatment, which changes the electrical conductivity of the fluids in the fractures.

\section{Summary}

In general, fracture networks with fractures of variable orientations, increased length, and high density provide additional water storage and an increased ability to transmit water. In fractured crystalline-rock aquifers with only a few interconnected fractures, flow is dominated by, and limited to, the interconnected fractures, which can cause anisotropy in the direction of ground-water flow. Thus, it is important to identify fracture locations and hydraulic properties to optimize the locations of boreholes prior to expanding a well field or initiating remedial activities. Borehole radar can be helpful for characterizing the fracture patterns in the aquifer surrounding the borehole and in designing and assessing the source-area remediation effort and its impact on the bedrock aquifer. Because the radar method can see beyond the borehole walls, it can be used to help map reflectors for understanding the site hydrogeology, locating new boreholes, or locating conductive tracers or contaminants. The purpose of this study was to evaluate the potential use of borehole radar to (1) map fractures in the bedrock surrounding the boreholes; (2) provide information for locating additional boreholes; and (3) evaluate radar as a tool for monitoring sourcearea remediation efforts.

Directional, single-hole borehole-radar investigations were conducted by the USGS in cooperation with the USACE in December 2003 in Machiasport, Maine. Two boreholes were logged as a part of a larger, ongoing Department of Defense and USACE environmental restoration program at the AFRTS site near Bucks Harbor. Single-hole radar-reflection methods appeared to work well at this site; the bimodal volcanic rocks propagated the signal very well.

Many fractures were interpreted in the radar data collected in this study. Although filtering the data removed several vertical features near the boreholes, numerous steep to nearly vertical features were observed away from the boreholes. Within this population of interpreted fractures, no large, unique fractures that might dominate flow in the bedrock were identified. Interference between signals from the numerous strong reflectors precluded the accurate determination of the location, strike, and dip of some reflectors. When the results of this investigation were compared to results of previously collected borehole-geophysical logs, the overall interpretations were consistent. The fractures mapped by the radar methods compare well with the borehole logging and the drilling data. Collectively, these data indicate that the rock underlying the Howard Mountain site is highly fractured, and that the fractures are oriented in a variety of directions; these are factors that greatly increase the likelihood of a highly interconnected fracture network. Because the rock surrounding the borehole is highly fractured, boreholes for monitoring or remediation would not have to be strategically placed to intersect a single transmissive fracture or fracture zone in the area surrounding the boreholes. Clusters of reflec- 
tors surrounding the borehole could be targeted for drilling; however, additional information on direction of flow, contamination, and source location also would be needed to site any new boreholes. Single-hole radar data collected for this investigation do not address whether these reflectors are fractures that can transmit large amounts of water or contaminants. Additional geophysical logging, hydraulic testing, and integrated analyses would need to be conducted to determine the hydraulic properties of, and contaminant distribution in, the fractures or fracture zones surrounding the boreholes.

Results from boreholes MW09 and MW10 showed that 60-100 MHz radar waves can penetrate 16 to $40 \mathrm{~m}$ into the rock surrounding the boreholes. These results indicate that a borehole separation of up to $20 \mathrm{~m}$ should support hole-to-hole radar tomography. The integrated drilling and borehole-geophysical logging results indicate the vitrophyre is more fractured than the more mafic gabbroic unit, and fracturing intensity is greater and more uniform near MW10 than MW09. The distribution of radar reflectors as displayed on the projection and tadpole plots indicates there is a fairly uniform distribution of reflectors over the open part of the borehole. Many of the reflectors dip at angles greater than $50^{\circ}$ from horizontal. There does not appear to be a quantifiable difference in the radar-wave penetration depths in these two formations. The high proportion of steeply dipping fractures and the low head in MW10 indicate the potential for downward flow and chemical migration to the aquifer.

Results from this investigation indicate borehole-radar reflection can be used effectively at this site for identifying reflections in the bedrock surrounding the boreholes. In addition, these results indicate hole-to-hole radar tomography might be effective for identifying features between boreholes. If the boreholes were strategically placed such that they straddle a transmissive zone, differencing tomography might be effective for imaging changes in the plane between the boreholes in response to a hydraulic stress on the system, such as pumping, or injection of a conductive tracer or injectate for source-area remediation. Prior to initiating active tracer tests and conducting differencing tomography, additional characterization of the fracturing and the local hydraulics should to be conducted to verify that the boreholes will straddle a contaminated transmissive zone, which is likely to change in response to an imposed hydraulic stress.

\section{Acknowledgments}

This was work done in cooperation with the USACE, New England Region, under MIPR W13G8633230292. The authors would like to acknowledge the support and assistance of Drew Clemens and Robert Leitch of the USACE. Additionally, the authors appreciate the technical assistance of Christopher Kochiss, Frederick Day-Lewis, and Eric White of the USGS. Finally, the authors are grateful to John W. Lane and Jason Sorenson for technical reviews of this work, and to Sandra Cooper for her final review of the manuscript.

\section{References Cited}

ABB Environmental Services, Inc., 1997, Engineering evaluation of contamination, Bucks Harbor Former Air Force Radar Tracking Station, Machiasport, Maine: Portland, Maine: Environmental Services, Inc., 76 p.

Borns, H.W., Jr., 1974, Surficial geology of the Machias quadrangle, Maine: Maine Geological Survey Open File No. 74-4.

Chapman, M.J., and Lane, J.W., Jr., 1996, Use of directional borehole radar and azimuthal square-array D.C. resistivity methods to characterize a crystalline-bedrock aquifer, in Bell, R.S., and Cramer, M.H., eds., Symposium on the Application of Geophysics to Engineering and Environmental Problems, Keystone, Colorado, April 28-May 2, 1996, Proceedings: Wheat Ridge, Colorado, Environmental and Engineering Geophysical Society, p. 833-842.

Davis, J.L., and Annan, A.P., 1989, Ground-penetrating radar for high-resolution mapping of soil and rock stratigraphy: Geophysical Prospecting, v. 37, p. 531-551.

Day-Lewis, F.D., Lane, J.W., Jr., Harris, J.M., and Gorelick, S.M., 2003, Time-lapse imaging of saline tracer tests using cross-borehole radar tomography: Water Resources Research, v. 39, no. 10, 14 p., 1290, doi:10.1029/ 2002WR001722.

Falk, L., 1992, Directional borehole antennas-Theory: Stockholm, Sweden, Stripa Project 92-16, SKB, 138 p.

Gates, O. 1981, Bedrock geology of the Machias, Columbia Falls, and Great Wass Island quadrangles: Maine Geological Survey, Department of Conservation, Open File No. 81-11.

Gates, O., and Moench, R.H., 1981, Bimodal Silurian and Lower Devonian volcanic rock assemblages in the MachiasEastport Area, Maine: U.S. Geological Survey Professional Paper 1184, 32 p., map at scale 1:62,500.

Green, Aaron, Lane, J.W., Jr., Johnson, C.D., Williams, J.H., Mondazzi, R.A., and Joesten, P.K., 2004, Combined use of borehole geophysics and packers to site potable wells in a contaminated area in Montville, Connecticut, in 2004 U.S. EPA/NGWA Fractured Rock Conference-State of the Science and Measuring Success in Remediation, Portland, Maine, Sept. 13-15, 2004, Proceedings: Westerville, Ohio, National Ground Water Association, CD-ROM, p. 295-307. Gregoire, Colette, Lane, J.W., Jr., and Joesten, P.K., 2004a, Application of borehole radar for monitoring steamenhanced remediation of a contaminated site in fractured limestone, Maine, USA, in Hack, R., Azzam, R., and Charlier, R., eds., Engineering Geology for Infrastructure Planning in Europe - a European Perspective, Lecture Notes in Earth Sciences: Berlin, Germany, Springer-Verlag, p. 385-392.

Gregoire, Colette, Lane, J.W., Jr., and Joesten, P.K., 2004b, The use of borehole radar tomography to monitor a steam injection pilot study in a contaminated fractured limestone, in EAGE (European Association of Geoscientists and Engineers) Near Surface Geophysics meeting, Utrecht, The Netherlands, 6-9 September, 2004, Proceedings: Houton, The 
Netherlands, European Association of Geoscientists and Engineers, 4 p.

Johnson, C.D., Dunstan, A.H., Mack, T.J., and Lane, J.W., Jr., 1999, Borehole-geophysical characterization of a fracturedbedrock aquifer, Rye, New Hampshire: U.S. Geological Survey Open-File Report 98-558, 61 p.

Johnson, C.D., Lane, J.W., Jr., Williams, J.H., and Haeni, F.P., 2001, Application of geophysical methods to delineate contamination in fractured rock at the University of Connecticut landfill, Storrs, Connecticut, in Symposium on the Application of Geophysics to Engineering and Environmental Problems, Denver, Colorado, March 4-7, 2001, Proceedings: Wheat Ridge, Colorado, Environmental and Engineering Geophysical Society, CD-ROM.

Lane, J.W., Jr., Day-Lewis, F.D., Versteeg, R.J., Casey, C.C., and Joesten, P.K., 2004, Application of cross-borehole radar to monitor field-scale vegetable oil injection experiments for biostimulation, in Symposium on the Application of Geophysics to Engineering and Environmental Problems (SAGEEP), Colorado Springs, Colorado, Feb. 22-26, 2004, Proceedings: Denver, Colorado, Environmental and Engineering Geophysical Society, CD-ROM, 20 p.

Lane, J.W., Jr., Haeni, F.P., Placzek, Gary, and Wright, D.L., 1996, Use of borehole-radar methods to detect a saline tracer in fractured crystalline bedrock at Mirror Lake, Grafton County, New Hampshire, USA, in Sixth International Conference on Ground-Penetrating Radar (GPR'96), Sendai, Japan, Sept. 30-Oct. 3, 1996, Proceedings: Sendai, Japan, Tohoku University Department of Geoscience and Technology, p. 185-190.

Lane, J.W., Jr., Haeni, F.P., and Williams, J.H., 1994, Detection of bedrock fractures and lithologic changes using borehole radar at selected sites, in Fifth International Conference on Ground-Penetrating Radar, Kitchner, Ontario, Canada, June 12-16, 1993, Proceedings: Kitchner, Ontario, Waterloo Center for Groundwater Research, p. 577-591.

Lane, J.W., Jr., Joesten, P.K., and Savoie, J.G., 2001, Crosshole radar scanning of two vertical, permeable, reactive-iron walls at the Massachusetts Military Reservation, Cape Cod, Massachusetts: U.S. Geological Survey Water-Resources Investigations Report 00-4145, 17 p.

Olsson, Olle; Falk, Lars; Forslund, Olof; Lundmark, Lars; and Sandberg, Eric, 1992, Borehole radar applied to the characterization of hydraulically conductive fracture zones in crystalline rock: Geophysical Prospecting, v. 40, p. 109-142.
Singha, Kamini, Binley, A.M., Lane, J.W., Jr., and Gorelick, S.M., 2003, Electrical imaging of tracer migration at the Massachusetts Military Reservation, Cape Cod, in Symposium on the Application of Geophysics to Engineering and Environmental Problems, San Antonio, Texas, April 6-10, 2003, Proceedings: Denver, Colorado, Environmental and Engineering Geophysical Society, CD-ROM, 11 p.

Shapiro, A.M., Hsieh, P.A., and Haeni, F. P., 1999, Integrating multidisciplinary investigations in the characterization of fractured rock, in Morganwalp, D.W., and Buxton, H.T., eds., U.S. Geological Survey Toxic Substances Hydrology Program-Proceedings of the Technical Meeting, Charleston, South Carolina, March 8-12, 1999: U.S. Geological Survey Water-Resources Investigation Report 99-4018C, v. 3, p. 669-680.

Thompson, M.D., Miller, S.F., and Davies, W.E., 2005, Geophysical investigation of the Formerly Used Defense Site Machiasport, Maine: Argonne, Illinois, Energy Systems Division Argonne National Laboratory, Sponsor Report, 119 manuscript $\mathrm{p}$.

USACE (United States Army Corps of Engineers), 2004, Howard Mountain site plan, prepared for the Formerly Used Defense Site Program: Concord, Massachusetts, United States Army Corps of Engineers New England District, 1 p. Weston Solutions, 2003, Remedial investigation report former Bucks Harbor Air Force Radar Tracking Station, Machiasport, Maine [draft September 2003 prepared for the U.S. Army Corps of Engineers New England District]: Manchester, New Hampshire, Weston Solutions, 617 p.

White, E.A., Thompson, M.D., Johnson, C.D., Abraham, J.D., Miller, S.F., and Lane, J.W., Jr., 2005, Surface-geophysical investigation of a formerly used defense site, Machiasport, Maine-February 2003: U.S. Geological Survey Scientific Investigation Report 2004-5099, 48 p. 